\title{
THE LUIS MEDINA ARCHIVE AT THE ART INSTITUTE OF CHICAGO
}

\author{
by \\ Sasha Furlani \\ B.A. (Honours), Trent University, 1999
}

A thesis project presented to Ryerson University

in partial fulfillment of the

requirements for the degree of

Master of Arts

in the program of

Film and Photographic Preservation and Collections Management

Toronto, Ontario 2017

(C) Sasha Furlani 2017 


\section{AUTHOR'S DECLARATION FOR ELECTRONIC SUBMISSION OF A THESIS}

I hereby declare that I am the sole author of this thesis. This is a true copy of the thesis, including any required final revisions, as accepted by my examiners.

I authorize Ryerson University to lend this thesis to other institutions or individuals for the purpose of scholarly research.

I further authorize Ryerson University to reproduce this thesis by photocopying or by other means, in total or in part, at the request of other institutions or individuals for the purpose of scholarly research.

I understand that my thesis may be made electronically available to the public. 


\section{THE LUIS MEDINA ARCHIVE AT THE ART INSTITUTE OF CHICAGO}

Master of Arts, 2017

Sasha Furlani

Film and Photography Preservation and Collections Management

Ryerson University

\section{Abstract}

This applied thesis project details the processing of photographic materials and ephemera collectively referred to in this report as the "Luis Medina Archive," housed at the Art Institute of Chicago since the death of Cuban-American photographer Luis Medina in 1985. This collection of materials has never been accessioned into the permanent collection of the AIC and has remained in bureaucratic limbo for most of its life at the museum. The contents of the archive were undocumented in the records of the Department of Photography and were functionally inaccessible for research and study. To address this issue, my project took an inventory of the $22,000+$ objects in the archive; created a database to house the results of this inventory; and provided a recommendation of a selection of prints and materials to add to the permanent collection. This project resulted in the addition of 101 prints to the permanent collection. 


\section{Acknowledgements}

Above all, I would like to thank my spouse, Jennifer Hartnel, for her love, support, suggestions, motivation, sharp-eyed editing, and her willingness share this adventure with me. Without her, none of this would have been possible.

I must express my immense gratitude to the Department of Photography at the Art Institute of Chicago, especially Collections Manager and Research Assistant Barbara Diener, Senior Conservator Sylvie Pénichon and the Richard and Ellen Sandor Chair and Curator Matthew Witkovsky, for hosting me for the duration of this project, supporting and guiding my work to meet their unimpeachable standards, and for making me feel like a part of their incredible team. It was an honour to briefly count myself among their ranks, within such an esteemed institution.

Next, for his guidance, insights, support and wonderful anecdotes, I wish to thank Professor Joel Snyder of the University of Chicago. As a first reader, his encouragement to see this project through, regardless of the hurdles, was as helpful as the unique perspective he so generously shared with me.

Thank you to my second reader, Professor Marta Braun of Ryerson University for her support throughout this program and her invaluable contributions to this work, which ensured it was presented clearly and contributed to this field.

Though it goes without saying, the entire faculty and administration of the Film and Photographic Preservation and Collections Management program at Ryerson University deserve special thanks for their support and encouragement throughout this program, and for providing an educational experience of immense satisfaction.

And last, but certainly not least, my heartfelt gratitude to my classmates with whom I shared this journey. Collectively, their strength, wisdom, guidance, and willingness to share made them each a crucial part of my experience. I look forward to sharing and furthering this profession with them in the years ahead.

I dedicate this work to my mother, Christa. 


\section{Foreword}

Near the completion of my residency at the Art Institute of Chicago, an opportunity to present my recommendations to the Chair of the department finally materialized. At this meeting, I displayed a substantial selection of prints from the 101 that met my criteria (outlined in the Recommendations section of this paper) and reviewed them with the Chair and the Collections Manager. Because of my rationale and justifications, it was decided that all 101 prints should be added to the permanent collection, pending the approval of the Department of Photography Acquisition Committee, at their meeting scheduled for December 2017.

In my final days at the AIC I created and populated catalogue records for all 101 objects, following the AIC's institutional standards. As many of the prints had not been properly stored, often missing interleaving or lying unprotected against one and other, I processed each print and/or mat to ensure it met basic standards of preservation, and had a unique object number paired to it, which matched its catalogue record. This was accomplished in my final days, and after draft versions of this paper had been submitted, but represents the ultimate success of the project. Because of my work, several prints that have been inaccessible for over 30 years will enter the permanent collection, making them visible for future research. The goal of this project was to improve the accessibility of this collection of materials for future use, and this result has secured that hope. 


\section{Table of Contents}

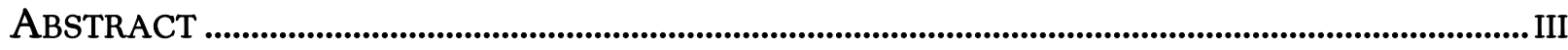

ACKNOWLEDGEMENTS ................................................................................................................

FOREWORD .........................................................................................................................................

TABLE OF CONTENTS ...............................................................................................................................

LIST OF PLATES ......................................................................................................................................................

LIST OF FIGURES ................................................................................................................................................. IX

PART I: THE CONTEXT .........................................................................................................

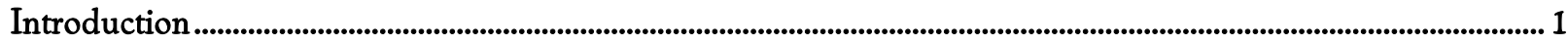

Literature Survey ................................................................................................................................................................................................ 4

The Art Institute of Chicago Collection...............................................................................................................................12

Luis Medina, Photographer ................................................................................................................................................................14

PART II: THE ARCHIVE........................................................................................................... 19

The Luis Medina Archive............................................................................................................................................................19

Getting Started ................................................................................................................................................................................21

Complete Inventory of Materials.............................................................................................................................................22

Results of the Inventory ......................................................................................................................................................................28

Recommendations .............................................................................................................................................................................

CONCLUSION.................................................................................................................................. 41

BIBLIOGRAPHY .......................................................................................................................................... 43 


\section{List of Plates}

Plate 1: Luis Medina Archive Racks 1 and 2, 2017. Courtesy of the author..............................2

Plate 2: Art Institute of Chicago Photography Study Room, 2017. Courtesy of the author.......13

Plate 3: Unknown, [Luis Medina]. Undated photograph circa 1980. Courtesy of the Art Institute

of Chicago.

Plate 4: Harold Allen, Part of Laser Project Conceived by José López and Luis Medina, Gelatin silver print with applied media, 1969. Courtesy of the Art Institute of Chicago. .......15

Plate 5: Luis Medina, [untitled], Silver dye-bleach print, 1980. Courtesy of the Art Institute of

Chicago.

Plate 6: Luis Medina, [untitled], Silver dye-bleach print, 1980. Courtesy of the Art Institute of

Chicago.

Plate 7: Luis Medina, [untitled], Silver dye-bleach print, 1980. Courtesy of the Art Institute of

Chicago.

Plate 8: Luis Medina, [untitled], Gelatin silver print, 1980. Courtesy of the Art Institute of

Chicago.

Plate 9: José López and Luis Medina, Joliet, Chromogenic print, 1971. Courtesy of the Art

Institute of Chicago.

Plate 10: José López and Luis Medina, Orlando, Florida, Chromogenic print, 1973. Courtesy of the Art Institute of Chicago.

Plate 11: Luis Medina, [untitled], Chromogenic print, 1977. Courtesy of the Art Institute of Chicago.

Plate 12: Luis Medina, [untitled, Gang Series], Silver dye-bleach print, no date. Courtesy of the Art Institute of Chicago. 36

Plate 13: Luis Medina, [untitled, Sons of the Devil Series II], Gelatin silver print, 1980. Courtesy of the Art Institute of Chicago. 36

Plate 14: Luis Medina, [untitled, Graffiti Series], Silver dye-bleach print, 1979. Courtesy of the Art Institute of Chicago. 
Plate 15: Luis Medina, Graffiti, Silver dye-bleach print, 1979. Courtesy of the Art Institute of Chicago.

Plate 16: Luis Medina, [untitled, Santería Worshipping], Silver dye-bleach print, 1981. Courtesy of the Art Institute of Chicago. 38

Plate 17: Luis Medina, Saints Feast (Santería Worshipping), Chicago, Silver dye-bleach print, 1980. Courtesy of the Art Institute of Chicago.

Plate 18: Detail of Medina slides on lightbox, 2017. Courtesy of the author............................39

Plate 19: unknown, Luis Medina, no date. Courtesy of the Art Institute of Chicago. 


\section{List of Figures}

Figure 1: Excel Worksheet of Luis Medina Archive, Container Contents ............................................ 25

Figure 2: Luis Medina Archive, Container Descriptions.......................................................................... 27

Figure 3: Inventory of Luis Medina Archive by Medium....................................................................... 28

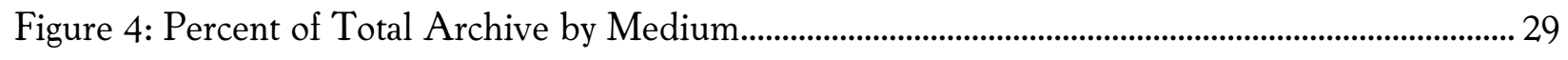

Figure 5: Luis Medina Archive Summary Report ........................................................................................... 30 


\title{
Part I: The Context
}

\begin{abstract}
"Now comes to the wall Luis Medina who knows well the traditions of art and photography. Camera in hand, precisely, deliberately, and with the greatest of care to make the correct translation of color, form, texture, and light, he preserves it, certifies it, cuts it out, and takes it home."

- Danny Lyon
\end{abstract}

\section{Introduction}

When the Cuban born photographer Luis Medina died in 1985 at the age of 43, the personal contents of his Chicago apartment were collected before the building's superintendent could dispose of them, and were brought to the Art Institute of Chicago (AIC). This was a natural landing place for these materials because the AIC had been one of Medina's most notable promoters and collectors, and already counted 44 prints of his in the permanent collection. Over the following years, another 59 prints would be acquired and accessioned into the permanent collection, bringing the total number of works to 103 prints. ${ }^{2}$ This places Medina into the top third of artist holdings in the Department of Photography's collection, which currently numbers over 22,000 photographs. Unfortunately, the vast amount of materials collected from his apartment were never accessioned or properly documented and have remained largely out of view ever since.

Shortly after beginning my residency in the AIC's Department of Photography, the opportunity to process the Luis Medina Archive was presented to me by the department's Collection Manager and Research Assistant, Barbara Diener. The department had long hoped to process this

\footnotetext{
1 Danny Lyon, "Urban Combat." Aperture no. 96 (Fall 1984), 30-33.

2 Medina often co-authored his work with his partner José López, and occasionally with American photographer Wayne Sorce. Please see pages 14-5 for additional details regarding this unique practice.
} 
collection of materials, and there had been one previous attempt to take an inventory of the holdings in the mid-1990s. Unfortunately, that information is entirely in hard-copy and was never digitized. As it has been over 20 years since that inventory was conducted, there is no way to assess its accuracy. Though I was not familiar with the life or works of Medina prior to arriving at the AIC, the opportunity to process the contents of an unrecorded collection of photographic materials and ephemera, and to potentially improve access to this collection could not be ignored, as it perfectly connects my own interests with the skills that this program has provided me.

To address the inaccessibility of the Luis Medina Archive, this applied thesis project will provide the AIC with a complete inventory of the contents of the archive; make the results of that inventory accessible through the construction of a database to house the results of the inventory; and finally, it will provide the Department of Photography with recommendations on how to handle or process the materials that are in agreement with its existing mandate, and suggestions for handling those that are not. My project will ultimately enable the Department of Photography to effectively manage a significant collection of materials within its possession, which could result

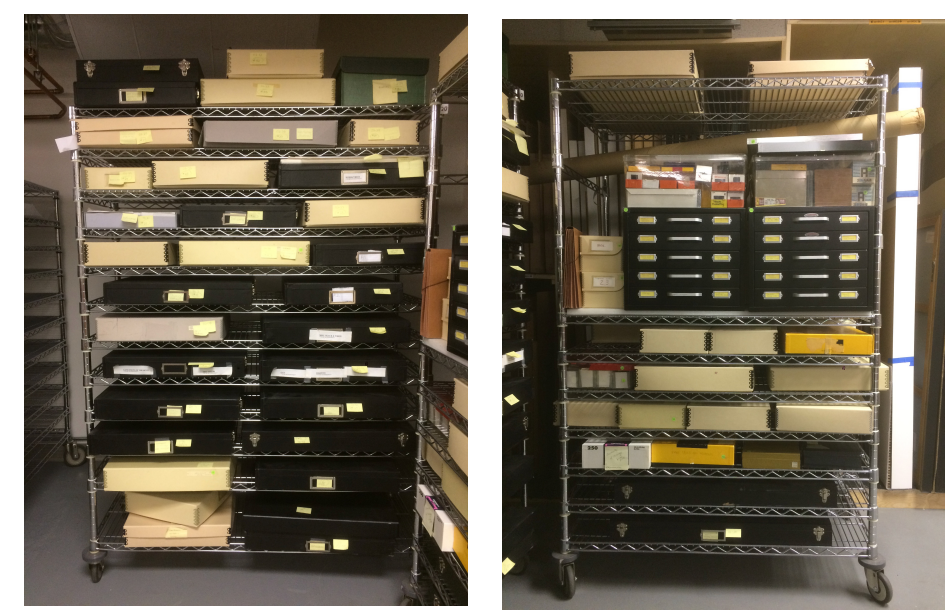

Plate 1: Luis Medina Archive Racks 1 and 2, 2017. Courtesy of the author. 
in the transfer of prints to its permanent collection. It will also ensure that any remaining materials are properly preserved and made accessible for future research. 


\section{Literature Survey}

As a practical project whose aim is to make a record of the unknown contents of an archive, there is no substitute for the simple, pragmatic approach of opening containers, counting the objects and making notes on them so they can be summarized and handled appropriately. There has been very little primary or secondary scholarship into the life and work of Luis Medina, however it remains important to understand the context of the materials contained within the archive so we can begin to assess their significance and motivate the tedious work needed to bring order where none exists.

For these reasons, this literature survey will review the following: a context for understanding the museum photography scene in Chicago during the period in which Medina operated (19701985), and to highlight his absence from these narratives; how Medina's work, both within the permanent collection of the AIC and within this archive, display themes linked to marginalized cultures that were not regularly seen in fine art museum contexts at this time; and finally, from a more practical perspective, a survey of resources that relate to the appraisal of archival materials, especially as they relate to the unique conditions of fine art collections and their relationship to archival materials that may not meet the mandate of the institution.

One of the key elements needed to understand the context of Medina's career as a photographer is to understand its location. Though his work, like many photographers, was made in many different places, the centrality of the city of Chicago to his work is undeniable. Both within the various collections that house his work, and in this archive, the predominance of Chicago-based images is obvious. To situate his work then, some appreciation of the history of photography in Chicago is necessary. 
This task is difficult because Chicago rarely garners more than a few lines in many histories of the medium. Within American art historian Mary Warner Marien's 2002 comprehensive overview of the medium, ${ }^{3}$ noted French historian Michel Frizot's 1997 volume dedicated to the same, ${ }^{4}$ or David Campany's own 2003 survey of art and photography, ${ }^{5}$ Chicago is usually mentioned only as a place where well known photographers operated, with no analysis or insight into its impact on the American culture of photography in the $20^{\text {th }}$ century. None of these volumes devotes any attention to the various institutions and support networks that nurtured the numerous photographic legends that passed through the city. When compared to how these tomes approach the now legendary institutions and key figures of New York City's scene, it is hard to believe that a similar degree of scholarship on Chicago would not enhance our understanding of $20^{\text {th }}$ century American photography.

That Chicago should deserve greater attention from historians seems obvious today, with so many important institutions and collections established in the city. The American art history professor Lloyd Engelbrecht positions Chicago alongside both New York City and San Francisco as important centres of American photography in the book that accompanied the Art Institute of Chicago's 2002 exhibition on the impact of the Institute of Design (founded by László MoholyNagy) on American photography. ${ }^{6}$ Though this volume focuses on the era preceding the career of Medina, it at least tries to position a key Chicago institution within the history of photography, and invites further scholarship. In this same publication, art history professor Keith Davis

\footnotetext{
3 Mary Warner Marien, Photography: A Cultural History (Upper River Saddle, NJ: Prentice Hall, 2002).

4 Michel Frizot, ed, A New History of Photography, (Köln: Könemann, 1998).

5 David Campany, Art and Photography, (London: Phaidon Press Limited, 2003).

${ }^{6}$ David Travis, and Elizabeth Siegel, Taken by Design: Photographs from the Institute of Design, 1937-1971 (Chicago: Art Institute of Chicago in Association with the University of Chicago Press, 2002), 17.
} 
demonstrates how widely the influence of the Institute of Design's (ID) was felt, largely as a result of being one of the first institutions to teach photography, and the caliber of the faculty teaching there. ${ }^{7}$ Furthermore, Davis also positions the ID among the institutions that together shaped the "photo-boom" that peaked in the late 1960s and 1970s. ${ }^{8}$

A final essay by American historian and archivist Larry Viskochil discusses the photography scene in Chicago from 1937-71, and includes the suggestion that the photographic community that evolved out of the ID, and more broadly across Chicago, produced a tradition based more on documentary rather than fine art. ${ }^{9}$ This may partially explain the lack of scholarship on the overall scene in Chicago, compared to other centres where fine art photography thrived, such as New York City. This documentary approach is an obvious theme in Medina's work, and is undoubtedly an echo of the under-examined influence of the tradition of photography in Chicago.

From a broader perspective, understanding the art scene in Chicago during the period of Medina's career is a little bit easier to do, thanks to the 1996 exhibition and catalogue produced at the Museum of Contemporary Art (MCA) located in Chicago. Interestingly, an essay by curators Lynne Warren and Staci Boris brings focus to the importance of neighborhoods and ethnicity in Chicago's Art scene following the second world war. ${ }^{10}$ This publication/exhibition included one of Medina's Latin-American gang photos, however there is little reflection on these connections to Medina's own practice. This publication only provides a generalized survey, but is a useful entry point to understanding the broader art community in Chicago during Medina's career.

\footnotetext{
7 Ibid. 69.

8 Ibid.

9 Ibid, 213.

10 Lynne Warren and Jeff Abell, Art in Chicago 1945-1995, (New York: Thames and Hudson, 1996), 84.
} 
Without even getting to the era that Medina worked in, there are clearly excellent opportunities for increased research into the role and influence of Chicago's photography scene on the larger history of photography in the United States in the $20^{\text {th }}$ century. A look through a few key histories of the medium indicated that little to no scholarship currently exists on this vast subject. The only significant exploration of the topic focuses on a single institution, and even then, that impact is discussed relative to Chicago alone. Attempts to connect this to the larger history of the medium are indirect at best. In the absence of any serious scholarship into the photography scene in Chicago in the 1970s and 1980s, and its impact on American photography within the $20^{\text {th }}$ century, it will remain difficult to effectively evaluate Medina's contributions to it.

One area of focus that has had an abundance of recent scholarship, and which has immediate implications for Medina's career, is his work documenting some of Chicago's marginalized communities. Latin American gang culture, LGBTQ lifestyle and culture, and Santería religious rites are the most represented among his work, and were not subjects that would have been easily found within the fine art photography galleries of Chicago in the 1970s and 1980s. As a gay Latin-American man Medina gained access to these cultures and photographed them from within, making it an important area of focus.

Canadian photography curator, Sophie Hackett's 2016 exhibition and publication titled, Outsiders, collected together a group of artists whose work provided a glimpse at new views of American society between 1950 and 1990. ${ }^{11}$ Hackett states that in this period an ethical movement encouraged insiders of otherwise outsider communities to begin capturing aspects of their lives, often with cameras, and the result was a significant shift in documentary practices that

\footnotetext{
${ }^{11}$ Sophie Hackett and Jim Shedden, Outsiders: American Photography and Film 1950s-1980s (New York: Skira Rizzoli Publications, Inc., 2016), 9.
} 
favoured closeness and membership over distance and objectivity. ${ }^{12}$ That Medina's work was not included in this project is not surprising, but what the exhibition and publication demonstrate are increased attention to non-traditional perspectives within film and photography scholarship, and Medina's work fits comfortably within this approach.

The most comprehensive text available about the life and career of Medina was published in 1993 to accompany what until now has been the last solo exhibition of his work. That show was created by former AIC photography curator David Travis, and the publication was titled: Facts and Fables by Luis Medina, Photographer. In it, Travis provides a comprehensive overview of Medina's life and career, and frequently mentions Medina's ability to document some of these groups due to the fact he was a Cuban-American expatriate in a northern city. ${ }^{13}$ The absence of any reflections on Medina's position as a gay Latin-American man in Chicago is especially of interest from a contemporary perspective, and his work documenting this community has gone unpublished. Travis does discuss Medina's photos of "graffiti, gangs and gays,"14 but does not explore these themes deeply, nor does the catalogue provide any images of the LGBTQ themes mentioned in the essay.

The previously mentioned survey on art in Chicago published by the MCA also makes mention of Medina's outsider subjects, ${ }^{15}$ and his work photographing Latin-American life in Chicago, LGBTQ lifestyles, gangs, and cult religious rites. ${ }^{16}$ However, this is only included in

\footnotetext{
12 Ibid, 12.

${ }^{13}$ David Travis, Facts and Fables by Luis Medina, Photographer (Chicago, IL: Art Institute of Chicago, 1993), 16.

14 Ibid, 17.

${ }^{15}$ Warren and Abell, 267.

${ }^{16}$ Ibid, 268.
} 
Medina's artist bio, and no attempt is made to provide a critical assessment of his work or its intersections with these subjects.

Returning to the histories of photography by Marien and Frizot, we can see that there remains a strong interest in understanding the contexts of various forms of social-documenting. Each publication contains significant sections to contextualizing these works (Marien's section on social change, and specifically socially concerned photography, ${ }^{17}$ and Frizot's chapters on humanism ${ }^{18}$ and on subjective reality ${ }^{19}$ ). These two publications demonstrate the importance that social documentary photography maintains as a topic in photographic scholarship, and the efforts to contextualize works that fit these classifications.

Medina's position within several marginalized communities within Chicago provides an interesting context for explorations into his work. As scholarship continues to focus on this genre of photography, Medina's work can provide an entry point for explorations of Latin-American culture in Chicago, gang cultures in a city that still struggles with these issues in the $21^{\text {st }}$ century, and a view towards queer space issues during the politically turbulent 1970s, and the onset of the AIDS crisis in the early 1980s. Such explorations could continue to extend much of the work already present in established histories of the medium.

Finally, a practical turn is needed to confront some of the specific issues that the Luis Medina Archive presents to the AIC. Though it is an encyclopedic institution, its mandate serves fine art acquisition, not archival practices. Space, and the resources to manage materials, are an everpresent concern, so an archive of over 20,000 objects presents a unique situation that the

\footnotetext{
17 Marien, 416.

18 Frizot, 613.

19 Frizot, 661.
} 
institution must consider. With little of the material in the archive classifiable as fine art, how can a fine art museum decide what to do with the thousands or proof prints, contact sheets, negatives, slides/transparencies, and ephemera?

Material assessment has always been a difficult subject, since no single set of guidelines could ever hope to cover all the various objects an institution might receive into its care. Collection management texts, such as Rebecca Buck's 2010 Museum Registration Methods are excellent resources for cataloguing, handling and storage practices, ${ }^{20}$ but they do not provide much for material assessment.

Turning to archival theory can provide some methodologies for handling collections, but as American archival theorist Reto Tschan makes clear in a 2002 paper on archival appraisal, there are two conflicting approaches to archive theory. ${ }^{21}$ Boiled down to their basics, one approach believes that keeping all materials is imperative, while the other believes a selection must be made in order to manage the volume of records being produced, while admitting the threat this presents to unknowable future research needs. Furthermore, the selective method does not present guidelines to follow, other than trying to understand the author's motivations when the items were created, and how they can impact future research. ${ }^{22}$ Since these two approaches consider the question from the perspective of bureaucratic records management, rather than fine art collection management, it is difficult to extrapolate from them.

\footnotetext{
${ }^{20}$ Rebecca A. Buck and Jean Allman Gilmore. MRM5: Museum Registration Methods. 5th ed. (Washington, DC: AAM Press, 2010).

21 Reto Tschan, "A Comparison of Jenkinson and Schellenberg on Appraisal." (Accessed April 26, 2017. americanarchivist.org/doi/pdf/10.17723/aarc.65.2.920w65g3217706I1), 177.

22 Ibid, 184.
} 
As a fine art collecting institution, it is difficult for the AIC to determine how to handle an archive of secondary materials from an artist held in its collection. Both collection management practices and archival theory are ill-equipped to provide guidance on handling a collection described here. Keeping and properly managing the entirety of an archive may present physical and economic constraints that may lead to unforeseeable issues, or prevent the institution from collecting other items of importance in the future. However, the alternative of judging the contents from our current perspective to determine what will remain and what may be disposed of seems presumptuous, as there is no way to know if discarded elements could prove to be crucial to future researchers. The risk is too great, and without guidelines of any kind, it would be guesswork at best, which can never be the basis for an appraisal.

To conclude, the literature surveyed for this research project demonstrates an unwarranted absence of scholarship on the career of Luis Medina. Understanding the context of his career is made difficult not just from the lack of literature about his life and practice, but also by the lack of scholarship on the photography scene in Chicago during his career, which would have had a significant impact on his work. Also, considerations of his work documenting marginalized cultures are lacking, even as scholarship on outsider photography and subjective documentary continue to grow. Positioning his work on Latin-American culture in a large American city, or on gangs or LGTBQ lifestyle, would surely be of benefit to researchers within those communities. That the Luis Medina Archive reflects each of these elements makes it an important resource for future potential scholarship. And finally, determining an effective methodology to handle the archival materials of an artist at a fine art collecting institution could be of benefit to this archive, and to other institutions that may encounter this challenge in the future. 


\section{The Art Institute of Chicago Collection}

The AIC itself is widely considered one of the outstanding encyclopedic museums in the United States of America, and is likely on a short list of similar institutions in the world. Since its founding in 1879, the AIC has grown its collection to include over 300,00 works of art, ${ }^{23}$ from cultures the world over, and across as many mediums as possible. Its close association with the School of the Art Institute of Chicago (SAIC) has also ensured that access to the collection and education in fine arts have remained priorities for the institution.

The Department of Photography was not established until $1975,{ }^{24}$ however the gift of a piece of the Alfred Stieglitz Collection by Georgia O-Keefe in 1949 made photography a collecting priority for the institution. While photography remained under the guise of the Prints and Drawings department, a series of assistant curators began to increasingly collect, advocate, and exhibit photography at the AIC, both historical and contemporary. Under the leadership of the now legendary curator Hugh Edwards in 1959, photography acquisitions increased as he demonstrated a deft touch for procuring valuable prints from as early as William Henry Fox Talbot, or spearheading then contemporary artists such as Robert Frank (whose first solo museum show was curated by him at the AIC ${ }^{25}$ ), Danny Lyon or Duane Michals to name a few. In fact, near the end of his tenure in 1969, Edwards would meet, and become an important mentor to Medina for the remainder of his life. ${ }^{26}$

\footnotetext{
23 "About." The Art Institute of Chicago. Accessed April 21, 2017. http://www.artic.edu/about.

24 David Travis, Photography in Chicago Collections: Selected to Illustrate the History of the Art of Photography and to Inaugurate the New Galleries and Facilities of the Department of Photography (Chicago: The Art Institute of Chicago, 1982), 16.

25 "Robert Frank." Hugh Edwards. (Accessed June 6, 2017. http://media.artic.edu/edwards/robert-frank/).

${ }^{26}$ Travis, 1993, 60.
} 
In 1975, under the leadership of David Travis, a separate Department of Photography was officially established. With this expansion came an important renovation to the department to increase the dedicated gallery space, as well as a study room, appropriate storage facilities, and a conservation laboratory. ${ }^{27}$ This new dedication to the medium also allowed for important acquisitions such as the Julien Levy Collection, a substantial gift of photographs from Edward Weston, and important purchases of masterworks by Eugène Atget, Andre Kertész, Paul Strand and others. $^{28}$ This legacy continues today under the guidance of the current Chair and Curator of the Department of Photography, Matthew Witkovsky and now numbers over 22,000 photographs spanning the history of the medium.

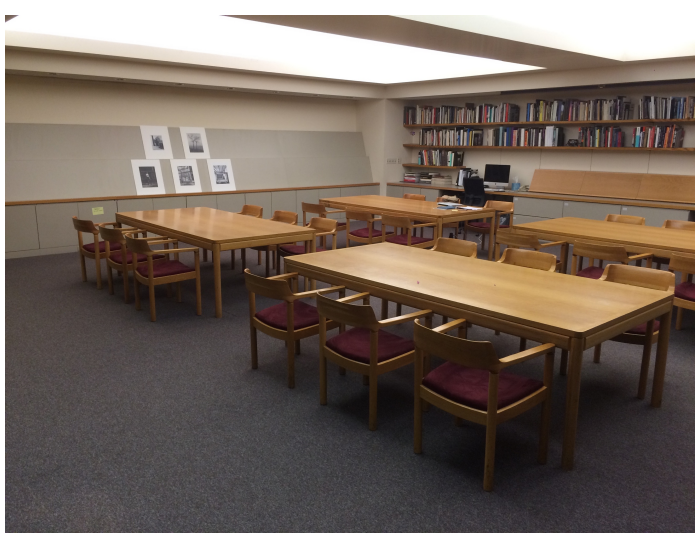

Plate 2: Art Institute of Chicago Photography Study Room, 2017. Courtesy of the author.

\footnotetext{
27 Travis, 1982, 16.

28 "Photography." The Art Institute of Chicago. (Accessed June 6, 2017. http://www.artic.edu/collections/photo).
} 


\section{Luis Medina, Photographer}

Luis Medina was unknown to me when I started processing his archive, and he remains an elusive figure more than 30 years after his death. Online searches of his name or work will only yield a few results, usually just links to his works held in various collections. However, the basic facts of his life are easy to recount, thanks to Travis' 1993 publication, ${ }^{29}$ which accompanied an exhibition of Medina's works held at the AIC that same year.

Born in Cuba in 1942, Medina left in 1958 with the onset of the Cuban revolution. He was not thrilled at his prospects with either of the parties that were fighting for control of the island nation. ${ }^{30}$ It is not clear whether Medina or his family had sympathies with either side, or simply feared the uncertainty of life in Cuba during this period.

Medina spent the next three years in Europe, mostly studying in Spain, before re-uniting with his mother in Miami, Florida. While there he worked mostly in menial labour jobs, usually in restaurants, and began taking college courses in art. Most importantly, he reunited with his childhood friend from Cuba, José López, who had also left Cuba during the revolution. López was studying art at the same college as Medina, and the two began a professional, and

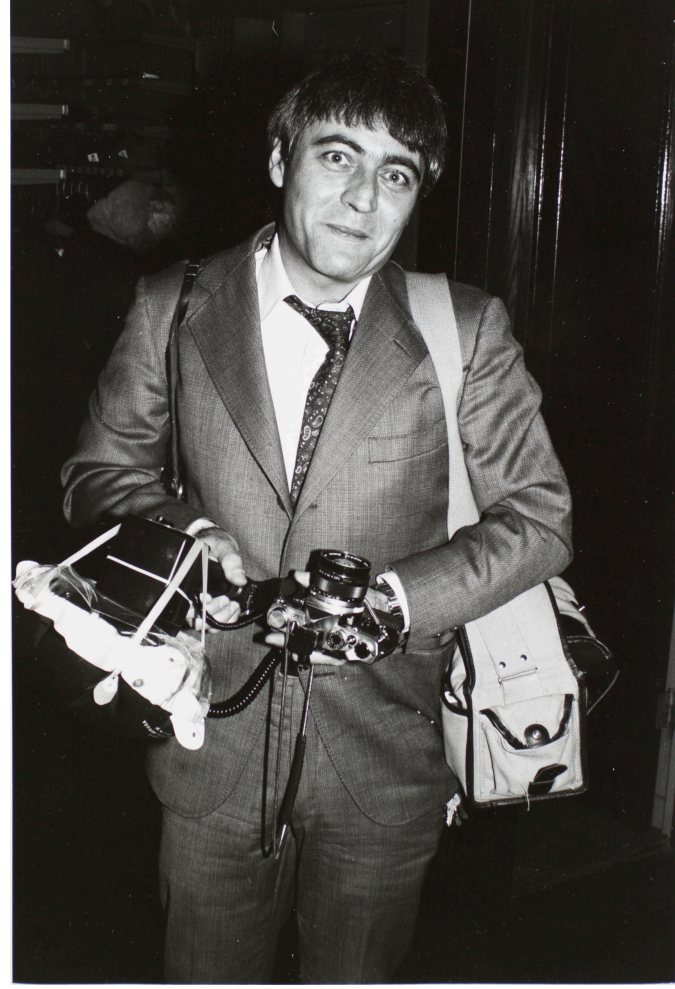

Plate 3: Unknown, [Luis Medina]. Undated photograph circa 1980. Courtesy of the Art Institute of Chicago.

\footnotetext{
${ }^{29}$ Travis, 1993.

30 Luis Medina. "Career Summary." 1981. Photocopy, Department of Photography, Art Institute of Chicago.
} 
possibly personal relationship, that would be a defining feature of their work for most of the next ten years. Unfortunately, this project was unable to uncover much factual information relating to the details José López's life.

With a growing interest in fine arts, specifically sculpture making, Medina and López moved to Chicago and enrolled in the School of the Art Institute of Chicago (SAIC). It was there that they met famed photography professor Harold Allen, who was helping them take photographs for a conceptual sculptural project involving lasers, the Hancock Tower, and the Lake Point Tower. Instead, this meeting ignited an interest in photography, leading them to change their major from sculpture to photography. This also resulted in them meeting another key influence on their lives and career, Hugh Edwards, who

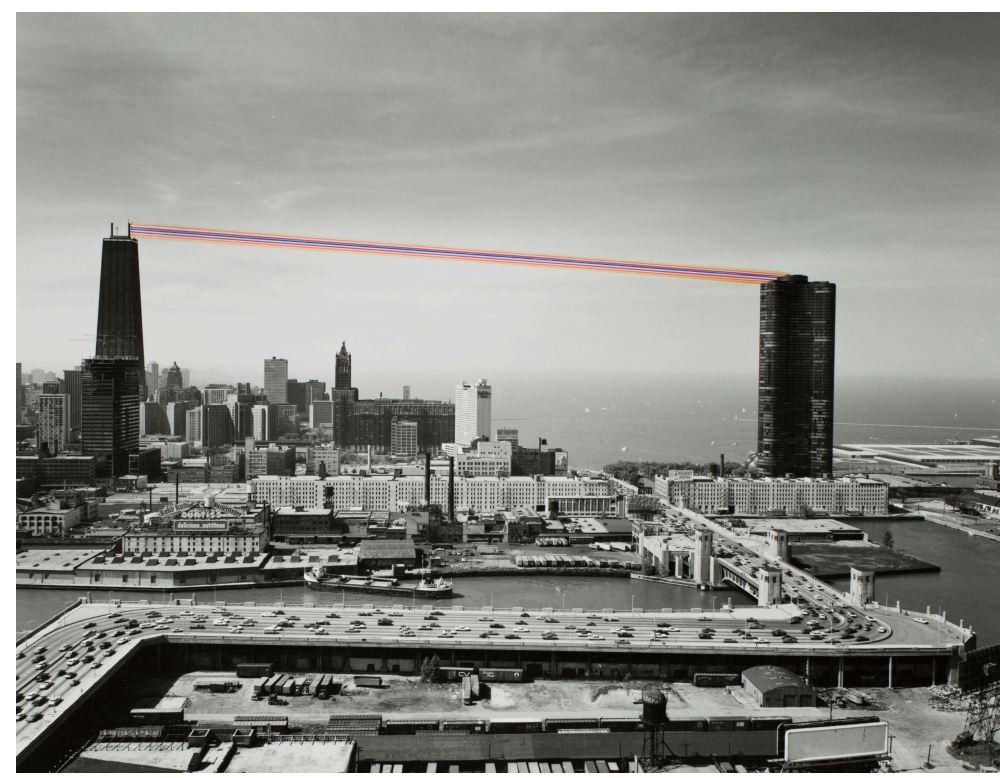

Plate 4: Harold Allen, Part of Laser Project Conceived by José López and Luis Medina, Gelatin silver print with applied media, 1969. Courtesy of the Art Institute of Chicago.

was coming to the end of his career as the photography curator at the AIC. By 1973 Medina had collected a BFA and a MFA in photography, and the pair were already publishing and exhibiting works in various publications and galleries. That same year also brought their first solo show at the AIC titled: Photographs by José López and Luis Medina. ${ }^{31}$

${ }^{31}$ Travis, 1993, 60. 
During this period Medina began teaching photography courses at various colleges around Chicago, and started receiving significant commissions, such as an architectural project about the University of Chicago that resulted in the publication: Dreams in Stone: University of Chicago; ${ }^{32}$ and an architectural project on the city of Quincy, Illinois which became an exhibition that toured the state. This commission was a documentary project for the American Revolutionary Administration to commemorate the bicentennial of the United States. Medina and López were also contributing to exhibitions in the US and abroad, as far away as Finland and Australia.

It is important to understand that during the time that Medina and López worked together, they always jointly attributed their work. In a document pulled from the archive, Medina explains the genesis of this unique arrangement:

"We started working together in 1968. This came about as we engaged in a photographic project involving the city of Chicago, which required the use of a view camera in situations where speed of operation was essential. As the project progressed we realized the advantages of this manner of working and by the time of it's (sic) completion we decided to continue working as a team." 33

In a 1977 interview with Nuestro Magazine, Medina explained the rationale for this arrangement:

"We quickly learned that although we had very different styles, we had a unity of vision. It's a matter of consensus. We reach our separate viewpoints, and then agree on a third viewpoint. After that, which one of us clicks the shutter is unimportant." 34

\footnotetext{
32 Patrice Grimbert, José López, and Luis Medina. Dreams in Stone: University of Chicago. (Chicago: University of Chicago Press, 1976).

33 Luis Medina, “José López-Luis Medina.” No date. Photocopy, Department of Photography, Art Institute of Chicago.

34 Unknown, “Gallery: Four Eyes - One Vision,” Nuestro Magazine, April 1977, 43-6.
} 
As such, all work from this period of their career (ranging approximately from 1969 to 1977), including their contributions to the publication Dreams In Stone, and their commission for the bicentennial project in Quincy, Illinois, is credited as: López-Medina.

Later that same year though, the pair decided to pursue individual artistic directions, and López left Chicago to reside in Miami, Florida, leaving Medina to his own devices. By remaining in Chicago, Medina could capitalize on the momentum that he and López had built over the previous eight years. This is evidenced by the numerous exhibitions in which his work was included. Most notably in 1980, the AIC gave Medina his own exhibition, which continued to grow his reputation as a photographer.

Commissions and exhibitions followed, but sometime in late 1984 or early 1985 Medina developed an infection, eventually diagnosed as cytomegalovirus. ${ }^{35}$ This neurological disease, which is linked to the AIDS virus, eventually killed him, on October 12, 1985. Seven years later in Miami, José López also died, at the age of 51, however the cause of his death was not determined during this project. It is also worth noting that I was unable to locate any evidence that José López continued to work as a photographer following his separation with Medina. If that information does still exist, it was outside the scope that this project could reasonably expect to address.

Though Medina's photographic career was relatively short, lasting only 15 years, it was nonetheless filled with accolades, commissions and exhibitions that would have been the envy of his peers. A solo exhibition at a museum as important as the AIC is proof of the stature of

35 Travis, 1993, 18. 
Medina's work, and its acceptance within the community of artists working in Chicago at the time. His premature death may be the reason that his work has remained largely unknown outside of Chicago, and the passage of time has continued to diminish its renown even there. This is the time to renew interest in his work, both in the holdings at various institutions, and through the materials left behind in his archive. 


\section{Part II: The Archive}

\section{The Luis Medina Archive}

The contents of the Luis Medina Archive are housed on two metal racks of 12 shelves each, which are stored in a secondary vault adjacent to the photography department offices, study room and main vaults. Upon gaining access to the archive, I determined that it was comprised of 78 unique containers, which included solander boxes, metal $35 \mathrm{~mm}$ slide storage drawers, archivalquality clamshell boxes and regular boxes. A brief visual inspection revealed that a wide variety of objects were contained within the containers, such as matted prints, loose prints, contact sheets, proof prints, slides, transparencies, negatives in various formats, notebooks, file folders of various papers, and even a few cased objects and glass plate negatives. At the start of this project, there was no reliable record of the total number of unique objects contained within the archive.

The archive came to the AIC after then curator, David Travis, helped empty out Medina's apartment following his death, before the building's superintendent could empty the unit out. A handwritten inventory of the materials that were brought into the AIC was made on October 11, 1985. ${ }^{36}$ This inventory does not contain item level information, and is too general to refer to for precise details, however it remains the only record of the initial acquisition. This document is currently housed in the Department of Photography's records. It is important to note that the materials collected in 1985 were not assigned object numbers, and were not accessioned into the holdings of the AIC.

${ }^{36}$ Unknown author, "Inventory of Archives of Luis Medina Taken on October 11, 1985." Photocopy, Department of Photography, Art Institute of Chicago. 
In the years following the arrival of the archive, there is little indication of what actions were taken to process its contents. Works by Medina were acquired by Travis following his death in 1985, but it is not clear if those prints were retrieved from the archive or elsewhere. In 1996, there was a full inventory of all containers made by the Department of Photography. This was done entirely on paper, and those results are stored in binders that now reside with the archive. For each page in the binder, there was supposed to be a matching page stored with the container. Based on my inspection of the containers, many pages have been lost in the intervening 20 years or containers have lost the identifying stickers that correspond to the inventory documents. This inventory is unreliable due to its age and its manner of organization. It is functionally inaccessible because it only exists in hard-copy, making it difficult to manage and produce summaries from.

However, the results of this inventory did contribute to the 1998 decision to formally acquire the entire archive from their legal owner, Medina's mother and sole heir, Olga Bohorques. This transaction was facilitated by a restricted gift of $\$ 20,000$, and is documented in the minutes of the Committee on Photography's acquisition meeting of March 24, 1998 ${ }^{37}$. The minutes also include the need to sort through the objects and select those to keep. Anything deemed unwanted or excessive, such as duplicates, would be returned to Ms. Bohorques. The minutes state, "In the next three months, we will review which prints to accession and which to return to Mrs.

Bohorques or her representative. This will allow us to keep only that part of the archive which is important to preserve and not house excessive materials or duplicates." ${ }^{38}$ It is unclear if this work was ever completed, but this document at least establishes the possession of the archive. The

\footnotetext{
37 Unknown author, “Committee on Photography Meeting Minutes, March 24, 1998." Photocopy, Department of Photography, Art Institute of Chicago.

38 bid.
} 
same file also contains the invoice for the transaction, signed by Olga Bohorques, dated April 25, 1998. ${ }^{39}$ These files will be important once the department determines how they wish to handle the pieces of the archive they do not wish to keep to ensure the legal transfer of the materials, possibly to other institutions or archives.

\section{Getting Started}

The uncertainty regarding the future status of the archive, along with its sheer size, meant that cataloguing the entire contents of the archive was impossible in the time and space allotted. With the aim of providing the AIC with a clear understanding of the contents of the collection, I determined that performing a full inventory of the 78 containers would be the best starting point. It is only with a complete understanding of the materials in its possession can the AIC determine how to appropriately handle them. Unfortunately, a lack of workspace and the size of the racks meant I could only access one rack at a time, which had to be kept in the primary storage vault that is connected to the study room, where I could work. This also meant that I had to work around the times that the study room was being used for classes, which was frequent during the school terms. $^{40}$

\footnotetext{
39 Unknown author, "Invoice, April 25, 1998." Photocopy, Department of Photography, Art Institute of Chicago.

40 The collection in the photography department is available to be seen by appointment, and many local schools and researchers make use of this access.
} 


\section{Complete Inventory of Materials}

Once the logistical issues were addressed for accessing the archive, I began the work of opening each container and making an inventory its contents. As each container was opened, items were grouped together as best as possible based on shared characteristics. These included print dimensions, negative formats, matted dimensions; medium type, subjects or themes noticed in the images, or any other characteristics. I made note of the item's medium, and when possible, I measured item groups for basic dimensions; any identifying inscriptions were also noted, and I recorded general observations on subjects or themes for future reference. I recorded this information in a manner that would make it easy to transcribe into the inventory database, using fields that would be useful for identifying objects in the future, and to conform to the standards the photo department uses for cataloguing objects. This would ensure that any objects identified for accession into the permanent collection could easily located and entered into the AIC's own proprietary database.

\section{Cataloging Database}

To handle the volume of information that would be generated by the inventory, I decided to create a custom digital repository to house the information. This would ensure easy access to the data and provide the ability to sort through the results quickly to create summaries and reports. Furthermore, having an updated inventory and a digital database would ensure that the AIC would have tools for working with the archive in the future. The absence of a reliable inventory 
and the tools to sort the data had been one of the limitations faced in previous attempts to organize the contents of this archive.

The platforms selected for the database were Microsoft Excel and Filemaker Pro. This was because they were available, easy to use, and supported easy migration between them and other platforms. The two spreadsheets were built with considerations for scalability issues so when the time came to migrate to Filemaker Pro, there were no import issues or lost data. Filemaker Pro is the database most commonly used within the Department of Photography, however the AIC has their own proprietary DAMS software that was developed in-house, called CITI. As an institutionally supported IT structure, adding and extracting information from CITI is a cumbersome and bureaucratic process that would not be feasible for this project. Hence, Excel and Filemaker Pro were chosen to keep the task simple and flexible.

To provide both specific and generalized views of the information, I created two distinct worksheets. One was a granular inventory of the contents, while the other provides a summary overview of each container. This provided flexibility in terms of reviewing the contents of the archive, and summarizing the results of the inventory for different users. In consultation with the Collection Manager, and adhering to both the American Library Association's guide to cataloguing cultural objects ${ }^{41}$ and the AIC's own cataloguing standards, I built an inventory database with the following categories (see Figure 1):

- Container \#: The unique identification number for each container in the archive. It is a fivecharacter code where the left two positions are the rack number, the right two positions are the container, and they are separated by a dash. 01-27 translates to rack number 01, container

\footnotetext{
41 Murtha Baca, Patricia Harpring, et al. Cataloguing Cultural Objects a Guide to Describing Cultural Works and Their Images. (Chicago, IL: American Library Association, 2006).
} 
number 27 .

- Medium: Used to place a work within a broader context, categorizing it based on simple characteristics. $^{42}$ Examples include: photograph, paper, album, etc.

- Object Type: Used to place a work within a narrow context, based on specific attributes or characteristics. Examples include: Gelatin silver print; Daguerreotype, Transparency, etc.

- Count: The sum of the total objects counted.

- Count Type: To refer specifically to the nature of the object being counted. Examples include: Prints, Mats, Pages, etc.

- Author: This field identifies the individual, group of individuals, corporate body, or other entity that contributed to creating, designing, producing, manufacturing or altering the work(s). ${ }^{43}$

- Title: Used to record the titles or identifying phrases given to a work of art of archival object. ${ }^{44}$

- Dates: Used to record the date or range of dates associated with the creation, design, production, or alteration of the work and its components. ${ }^{45}$

- Dimensions: Used to provide information on the dimensions, size or scale of the work. ${ }^{46}$ Information is always indicated in centimeters, and distinguishes if the dimension is the image (i), the paper $(\mathrm{p})$, or the mat $(\mathrm{m})$.

- Format: Used primarily to specify the format of photographic negatives; (e.g. $35 \mathrm{~mm}=35$ millimeter roll of film).

- Inscriptions: This field transcribes any distinguishing or identifying physical letter, annotations, texts, markings or labels found on an object. ${ }^{47}$

\footnotetext{
42 Ibid, 237.

43 Ibid, 77.

${ }^{44} \mathrm{Ibid}, 49$.

45 Ibid, 157.

46 Ibid, 104.

47 Ibid, 140.
} 
- Locations: Used to indicate any locations of where the materials were made based on observations and/or inscriptions.

- Subjects/Themes: Used to record any obvious themes or subject based on observations and/or inscriptions; and used to group similar works together.

- Description: This field consists of a descriptive note that is a general detailing of the content and/or context of the work.

- Remarks: This field provides for the recording of any observations or otherwise notable pieces of information observed by the cataloguer.

- Possible Destinations: This field provides for the recording and speculation of possible destinations for the object(s) described.

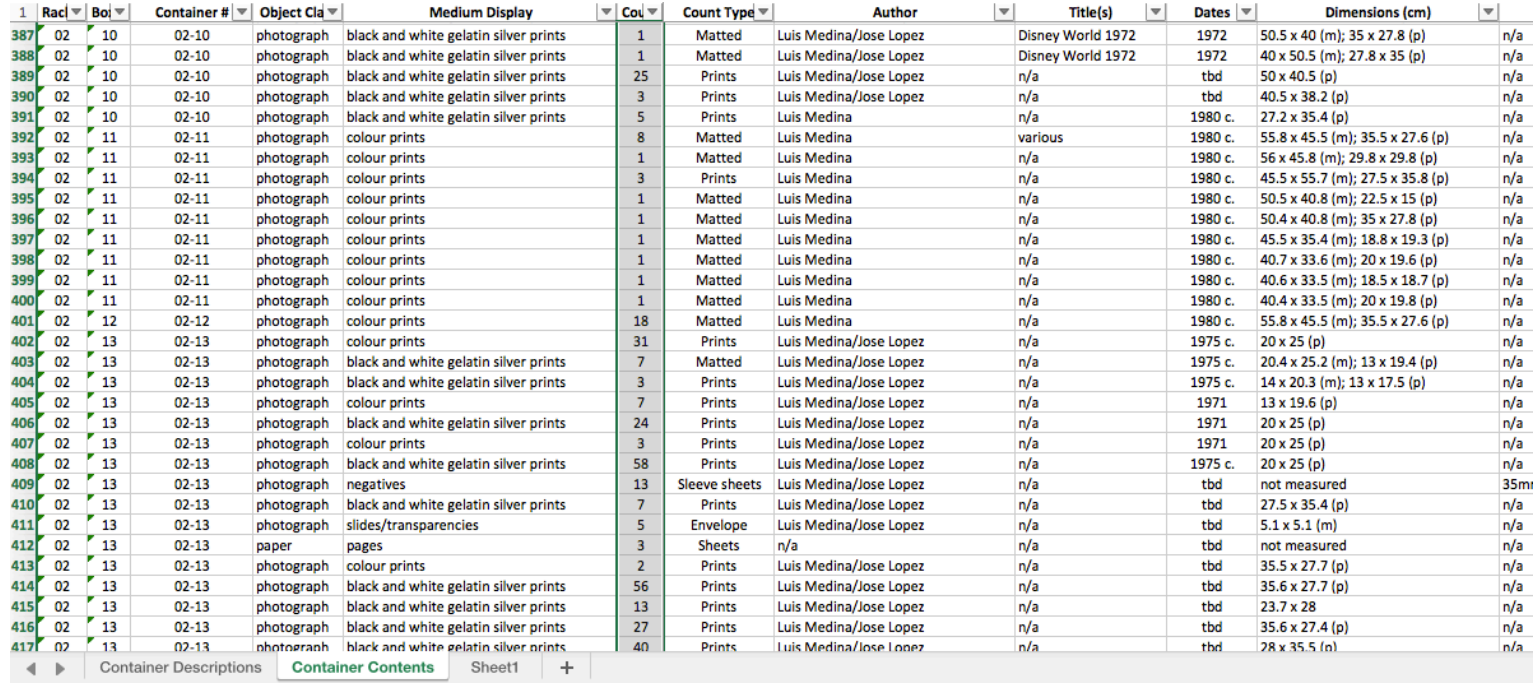

Figure 1: Excel Worksheet of Luis Medina Archive, Container Contents

The container summary table shares many of the same categories as this previous table, but with a few exceptions (see Figure 2). It is comprised of the following categories:

- Container \#: The unique identification number for each container in the archive. It is a fivecharacter code where the left two positions are the rack number, the right two positions are the 
container, and they are separated by a dash. 01-27 translates to rack number 01, container number 27.

- Container Type: Used to describe the container being identified. Examples include: Solander box, Archival clamshell box, Cardboard box, etc.

- Object Type: Used to place a work within a narrow context, based on specific attributes or characteristics. Examples include: Gelatin silver print; Colour prints, Slides, etc. This also provides a summary of the contents of each container.

- Total Objects: The sum of the total objects counted in the container.

- Author: This field identifies the individual, group of individuals, corporate body, or other entity that contributed to creating, designing, producing, manufacturing or altering the work(s).

- Dates: Used to record the date or range of dates associated with the creation, design, production, or alteration of the work and its components.

- Container Inscriptions: This field transcribes any distinguishing or identifying physical letter, annotations, texts, markings or labels found on an object. ${ }^{48}$

- Subjects/Themes: Used to record any obvious themes or subject based on observations and/or inscriptions; and used to group similar works together.

- Description: This field consists of a descriptive note that is a general detailing of the content and/or context of the work.

- Remarks: This field provides for the recording of any observations or otherwise notable pieces of information observed by the cataloguer.

48 Ibid, 140. 


\begin{tabular}{|c|c|c|c|c|c|c|c|c|}
\hline$\frac{1}{32}$ & Container \# & Container Type & Object Types & Total Objects & $\begin{array}{lll}\text { Authors } \\
\text { iverums }\end{array}$ & $\begin{array}{l}\text { Dates } \\
\text { c.lyou }\end{array}$ & Container Inscriptions & $\begin{array}{l}\text { Subjects/Themes } \\
\text { Jupie westimuouects }\end{array}$ \\
\hline 33 & $01 \cdot 31$ & Solander box & Gelatin silver prints; colour prints; negatives & 288 & Lopez-Medina & c. 1975 & $\mathrm{n} / \mathrm{a}$ & Harding collection; riverside; grafitti; misc \\
\hline 34 & $01 \cdot 32$ & Solander box & Gelatin silver prints & 677 & Medina & c. 1980 & proof prints & Adam H Olbert; UofC; architecture; vintage reproductions \\
\hline 35 & $01-33$ & Removable lid box - archival & I Negatives; colour prints; gelatin silver prints & 651 & Medina & c.1980 & gangs & Wedding; AlC; statues \\
\hline 36 & $01-34$ & Removable lid box - archival & I Negatives & 163 & Medina & c.1980 & Misc & Clubs; storefronts; misc \\
\hline 37 & $01-35$ & Clamshell box - archival & Negatives; slides & 238 & Medina & c.1980 & Transparencies 2; graffiti 3 & Graffiti; weeds; gangs; trees \\
\hline 38 & $01-36$ & Metal shelf cabinet & Slides/transperencies & 2333 & Medina & c.1980 & $n / a$ & graffiti; nature; shows; Mexico 1978; Fall; Weddings; lands \\
\hline 39 & $01-37$ & Metal shelf cabinet & Slides/transperencies & 2514 & Lopez-Medina & c.1980 & $n / a$ & Chicago; Aerials; Gay life; Bands; lakefront; Florida 1977 \\
\hline 40 & $01-38$ & <odak Elite Fine Art Paper Bo: & Gelatin silver prints & 24 & Lopez-Medina & c.1975 & $n / a$ & Miami; Chicago; Hyde Park; aerial \\
\hline 41 & 01-39 & Plastic box/container & Negatives; gelatin silver prints; slides & 881 & Medina & c.1980 & $n / a$ & architecture; weeds; graffiti; art repro \\
\hline 42 & $01-40$ & Removable lid box - archival & I Slides/transperencies; gelatin silver prints & 1815 & Lopez-Medina & c.1975 & $n / a$ & various \\
\hline 43. & $01-41$ & Cardboard box & Negatives; prints; slides & 494 & Lopez-Medina & c.1975 & n/a & gay life; architiecture; various \\
\hline 44| & $01-42$ & Cardboard box & Negatives; prints; notebook; photo album & 147 & Medina & c. 1980 & Medina Estate $35 \mathrm{~mm} \& 21 / 4 n$ & n streets; airport; book of condolences; letters; legal docume \\
\hline 45 & $01 \cdot 43$ & Cardboard box & Papers & $?$ & Various & $1969-1986$ & $n / a$ & paperwork; letters; invoices; various \\
\hline 46 & 01.44 & Tube & Gelatin silver prints & 1 & Medina & c.1980 & Luis Medina Photo of Chicago & Aerial; Chicago \\
\hline 47 & $01-45$ & Cardboard box & Daguerreotype; Ambrotype; Tintype & 7 & unkown & undetermined & Lewis Hine Lantern Slides (dub & i historical processes \\
\hline 48 & 02-01 & Removable lid box - archival & Gelatin silver prints; negatives; slides; papers & 465 & Lopez-Medina & c.1975 & Misc negs & Chicago; UofC; architecture; textbooks; businesses \\
\hline 49 & 02.02 & Removable lid box - archival & I Slides/transperencies & 61 & Medina & c. 1980 & Transparencies in Plastic Sleev & (c Chicago; festivals; Polish; Puerto Rican \\
\hline 50 & $02-03$ & Removable lid box - archival & Gelatin silver prints; colour prints & 69 & Medina & c. 1980 & Duplicates & Chicago; houses; boys; street; advertising \\
\hline 51 & $02-04$ & Solander box & Gelatin silver prints; colour prints & 233 & Lopez-Medina & c.1975 & n/a & UofC; architecture; Chicago \\
\hline 52 & $02-05$ & Solander box & Notebooks; magazines; ephemera & 107 & Lopez-Medina & c.1980 & Lopez-Medina sell/keep & Checklists; notes; degrees; ephemera \\
\hline 53 & 02.06 & Solander box & Gelatin silver prints & 44 & Lopez-Medina & c.1975 & $n / a$ & various \\
\hline 54 & $02-07$ & Solander box & Gelatin silver prints; colour prints & 119 & Lopez-Medina & c.1975 & Contents of theis box Not to ke & e gangs; travel; Miami; weeds; street \\
\hline 55 & 02.08 & Solander box & Gelatin silver prints; colour prints & 76 & Lopez-Medina & c.1975 & $n / a$ & architecture; Chicago; AIC; details \\
\hline 56 & $02-09$ & Solander box & Gelatin silver prints; papers & 444 & Lopez-Medina & c.1975 & Misc B/W Proofs & Quincy; gay parade; street; various \\
\hline 57 & $02-10$ & Solander box & Gelatin silver prints & 40 & Medina & c. 1980 & Trees & trees; lakefront; chicago; Disneyland \\
\hline 58 & $02-11$ & Solander box & Colour prints & 18 & Medina & c.1980 & Gangs/Sons of the Devil; To Be & gangs; portraits; interiors; architecture; Puerto Rican Pride \\
\hline 59 & $02 \cdot 12$ & Solander box & Colour prints & 18 & Medina & c.1980 & Gay; Graffiti; Santero; To Be Ac & c gay life; Igbtq; graffiti; santera \\
\hline 60 & $02-13$ & Solander box & Gelatin silver prints; colour prints; negatives; paper & 302 & Lopez-Medina & c.1975 & Quincy + Misc & carnivals; street festivals; people; Quincy; architecture \\
\hline 61 & $02-14$ & Solander box & Colour prints; gelatin silver prints & 26 & Lopez-Medina & c.1975 & Misc Black and White + colour; & mounted quality prints \\
\hline 62 & $02-15$ & Solander box & Gelatin silver prints; colour prints & 95 & Lopez-Medina & c.1975 & Quincy III; B/W & Quincy; architecture \\
\hline 4 & • & ontainer Descriptions & Container Contents & & & & & \\
\hline
\end{tabular}

Figure 2: Luis Medina Archive, Container Descriptions 
Once the inventory was completed, the database showed that there is a total of 22,341 unique objects in the archive. To put that in perspective, that is almost equivalent to the current total holdings of the Department of Photography! The dispersal of objects by Object Type is illustrated in Figure 3 below:

\begin{tabular}{|c|c|}
\hline Object Type & Total \\
\hline colour slides/transperencies & 8,958 \\
\hline black and white gelatin silver prints & 7,057 \\
\hline negatives & 4,443 \\
\hline colour prints & 1,634 \\
\hline pages & 121 \\
\hline instant black and white gelatin silver prints & 62 \\
\hline notebooks & 24 \\
\hline magazines & 10 \\
\hline folders & 8 \\
\hline misc & 5 \\
\hline daguerreotype & 4 \\
\hline books & 3 \\
\hline glass negatives & 2 \\
\hline newspapers & 2 \\
\hline posters & 2 \\
\hline tintypes & 2 \\
\hline address book & 1 \\
\hline ambrotype & 1 \\
\hline mixed media & 1 \\
\hline portfolio & 1 \\
\hline Grand Total & 22,341 \\
\hline
\end{tabular}

Figure 3: Inventory of Luis Medina Archive by Object Type 
Figure 4 presents a graph that summarizes this information by medium, and shortens the list to combine miscellaneous items into a single category:

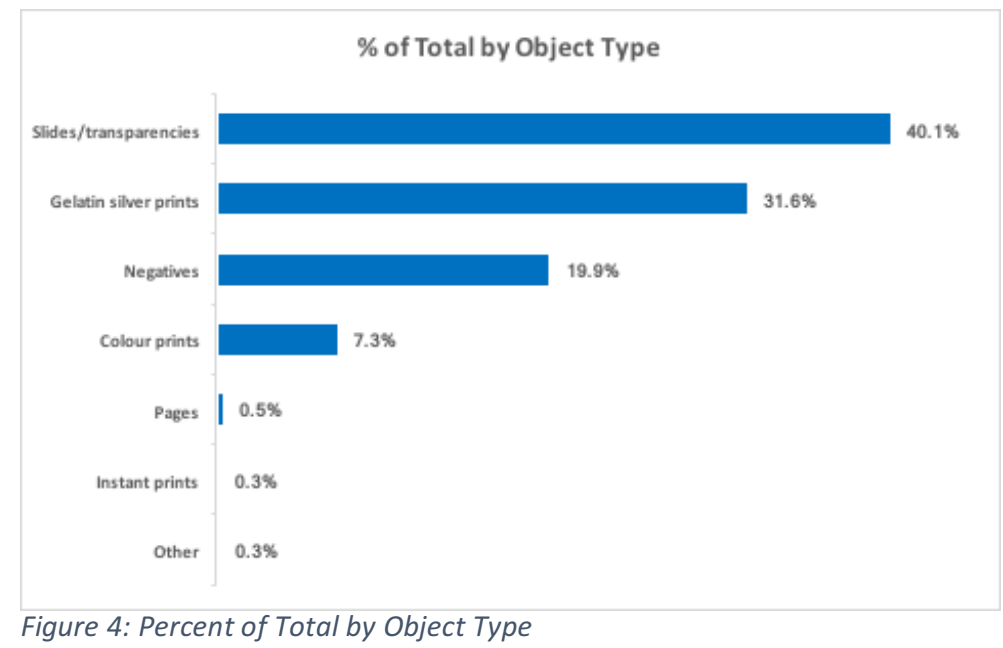

This summary indicates that 40 percent of the total archive is comprised of slides or transparencies. This is not surprising given the era in which Medina produced his work. Most slides are colour, and were likely used by Medina as working negatives. From this array of slides, he would select works to print, or he might provide them to clients for evaluation.

Gelatin silver prints represent the next largest grouping, with almost 32\% of total objects. These include prints that are matted (766 total) and unmatted (7,925 total). The unmatted total is inflated by the fact that that many of the prints are proof prints, tests, or contact sheets.

Negatives represent almost 20 percent of the archive, but this number is understated because, in the interests of time, when strips of negatives were housed in a plastic sheet (usually 5 to a sheet for $35 \mathrm{~mm}$ film), they were counted as a single object. It is likely that if negatives were counted by frame, they would easily be the largest component of the archive. 
It is also worth noting that ephemera, such as notebooks, correspondence, and the various paper materials in the archive, were counted individually, however if they were measured per archival standards, they would measure between 0.5 and 1 meter collected together.

I created a one page summary report to provide the department's Director and Collections Manager with a simple overview of the collection (Figure 5). This included the same data provided in the tables above, but also a few contextual notes relevant to the collection, such as a description of what objects comprised the ephemera in the collection, and a few notable points that were relevant to the collection. This information was presented at a meeting on June 6, 2017. At this meeting, I displayed a sampling of the contents of the archive in the Study Room to provide an example of the materials present within the archive. Through this meeting, we discussed some ideas on how the collection might be handled. There was a general feeling of

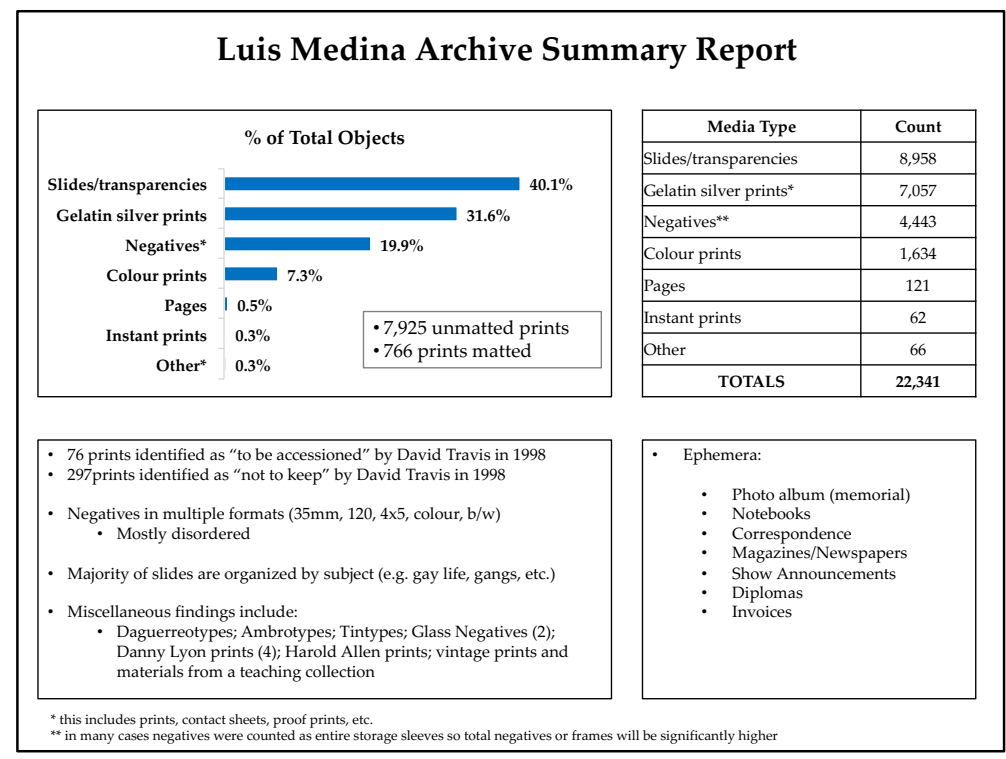

Figure 5: Luis Medina Archive Summary Report

amazement at seeing some of the different materials displayed in the study room, and relief at having a thorough summary of the contents of the archive from which they could then determine what could be done with the materials. There was also excitement about the quality and subjects of some of the prints I displayed, some of which were unknown to the Director and the Collections Manager prior to our review. 


\section{Recommendations}

The discussions at this meeting determined that adding all 22,341 objects to the permanent collection was not possible. The time needed to process and catalogue such a quantity of objects would extend far beyond the capabilities available to the department. Furthermore, as a fine art museum, it was not within the mandate of the institution to house a complete archive. The mandate states:

"The Art Institute of Chicago collects, preserves, and interprets works of art of the highest quality, representing the world's diverse artistic traditions, for the inspiration and education of the public and in accordance with our profession's highest ethical standards and practices." 49

It was agreed by the department's Director, Collections Manager, and myself that a solution should be sought that would allow the AIC to increase their collection of Medina prints, and possibly a selection of $35 \mathrm{~mm}$ slides, by a modest amount, and then begin seeking out another archive or institution that would be able to take the archive, process it fully, and ensure its accessibility to researchers and the public. Based on the results of the inventory, and my understanding of both the content of the archive and the Medina holdings at the AIC, I made the following recommendations:

- Transfer prints to the permanent collection that include Medina's work capturing Chicago's LGBTQ scene. This will fill a hole in the collection's holdings, as there are currently no works

49 "Mission." The Art Institute of Chicago. Accessed June 13, 2017. http://www.artic.edu/about/mission-andhistory. 
that represent this aspect of his work. Examples of the works can be seen below in plates 5, 6, 7 and 8.

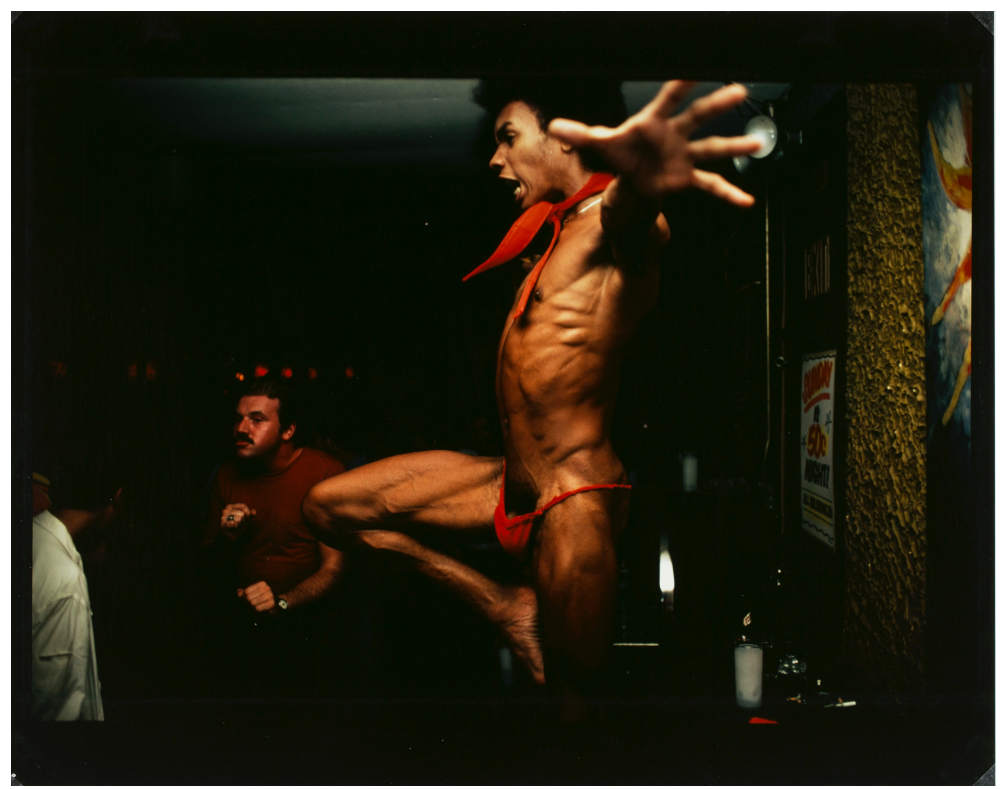

Plate 5: Luis Medina, [untitled], Silver dye-bleach print, 1980. Courtesy of the Art Institute of Chicago.

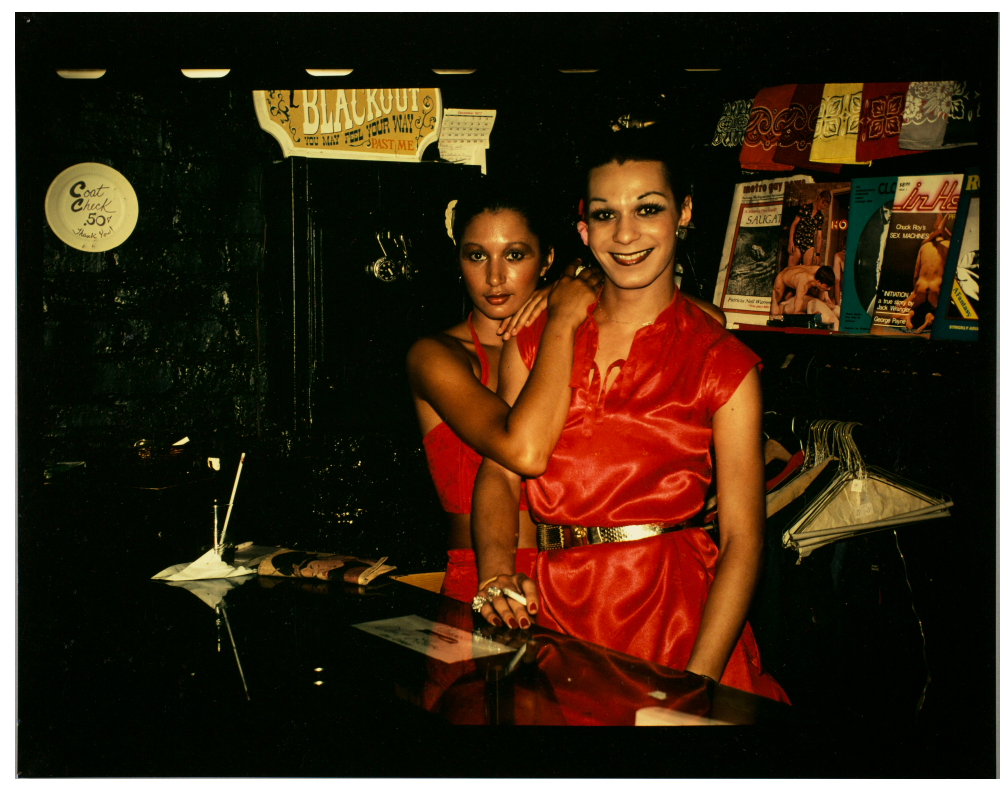

Plate 6: Luis Medina, [untitled], Silver dye-bleach print, 1980. Courtesy of the Art Institute of Chicago. 


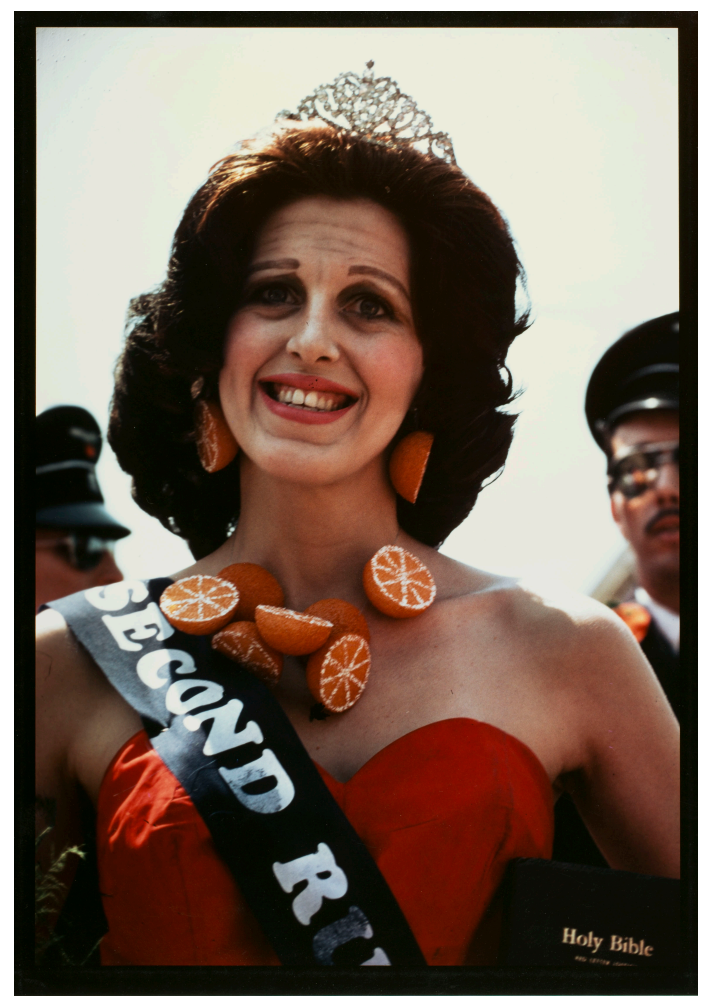

Plate 7: Luis Medina, [untitled], Silver dye-bleach

print, 1980. Courtesy of the Art Institute of Chicago.

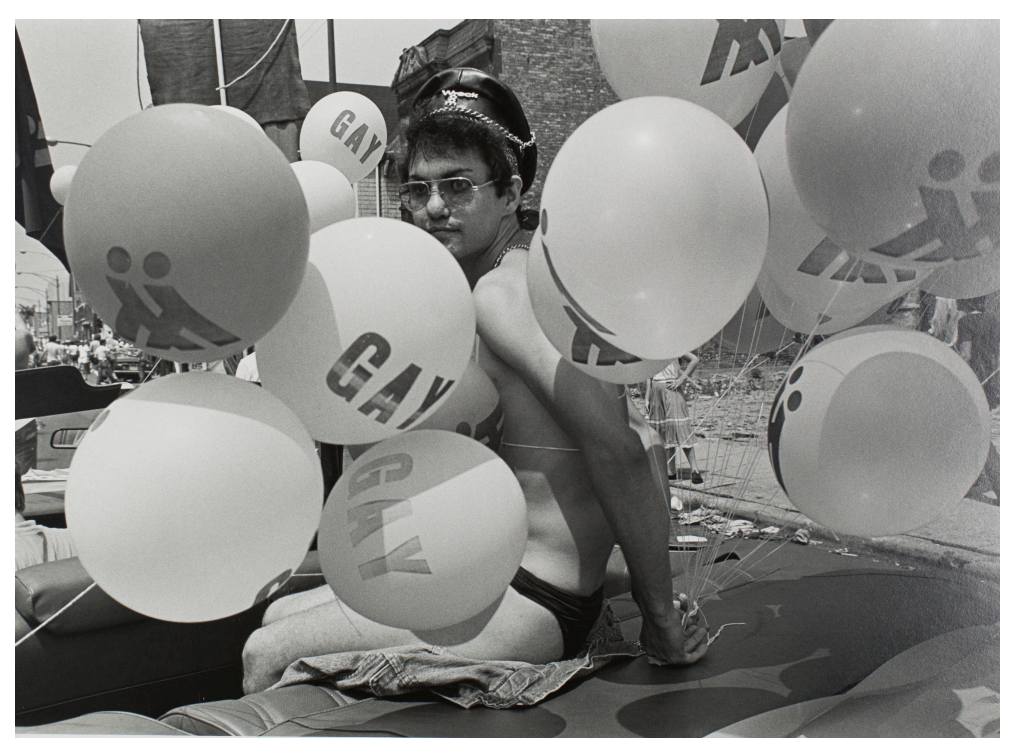

Plate 8: Luis Medina, [untitled], Gelatin silver print, 1980. Courtesy of the Art Institute of Chicago. 
- Transfer prints from the archive that were shown in exhibitions at the AIC or other institutions.

Examples include Plate 9, shown at the AIC and the Amos Andersonin Taidemuseo, Finland in 1973; Plate 10 shown at the San Francisco Museum of Modern Art in 1977; or Plate 11 shown at the Museum of Contemporary Art Chicago in 1977.

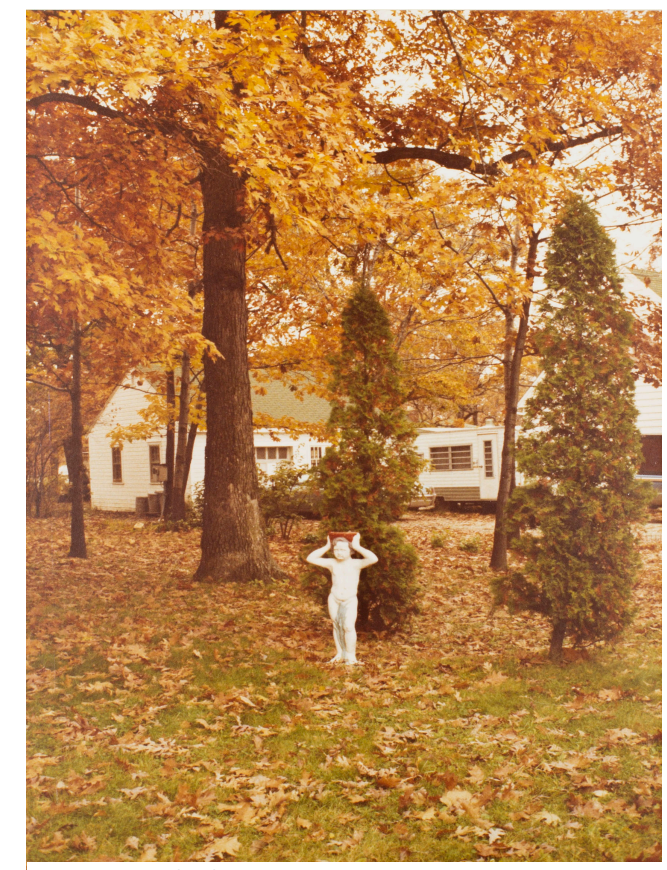

Plate 9: José López and Luis Medina, Joliet, Chromogenic print, 1971. Courtesy of the Art Institute of Chicago.

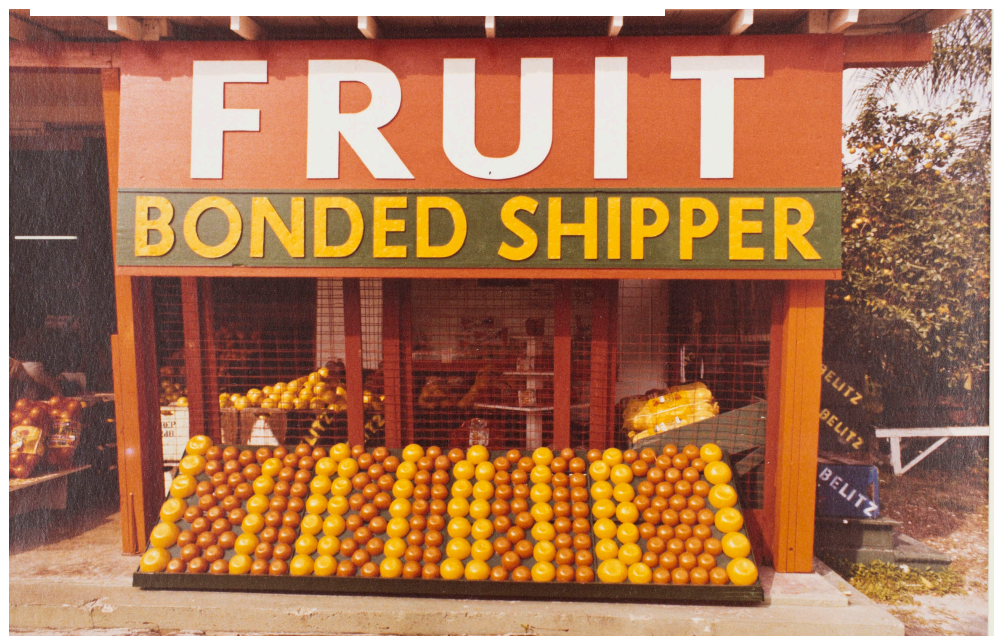

Plate 10: José López and Luis Medina, Orlando, Florida, Chromogenic print, 1973. Courtesy of the Art Institute of Chicago. 


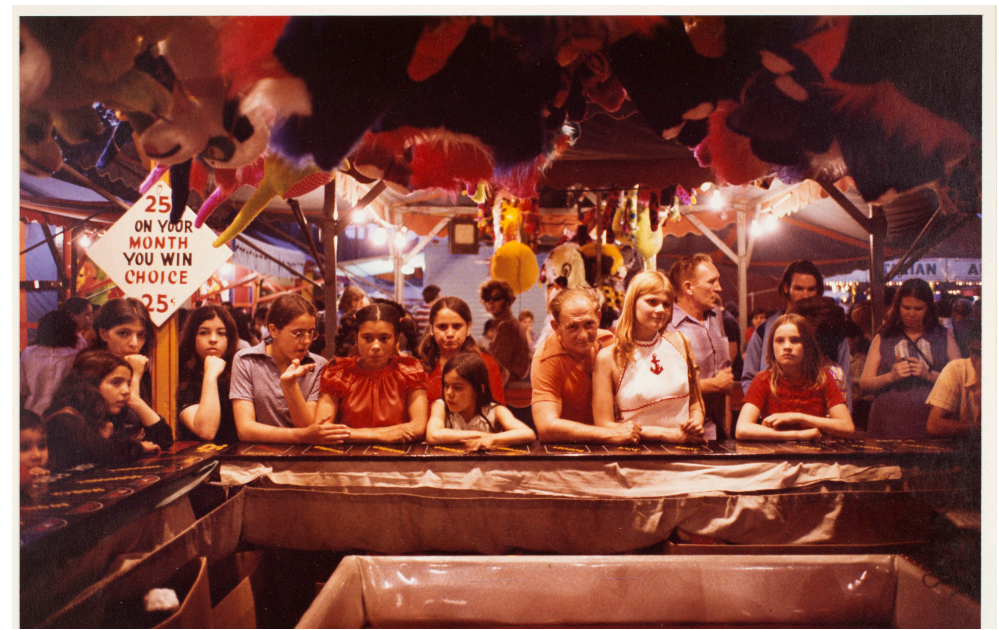

Plate 11: Luis Medina, [untitled], Chromogenic print, 1977. Courtesy of the Art Institute of Chicago. 
- Transfer prints that expand the context and understanding of works currently held in the permanent collection. This includes: Gangs (Plates 12 and 13); Graffiti (Plates 14 and 15) or Santería religious rites (Plates 16 and 17).

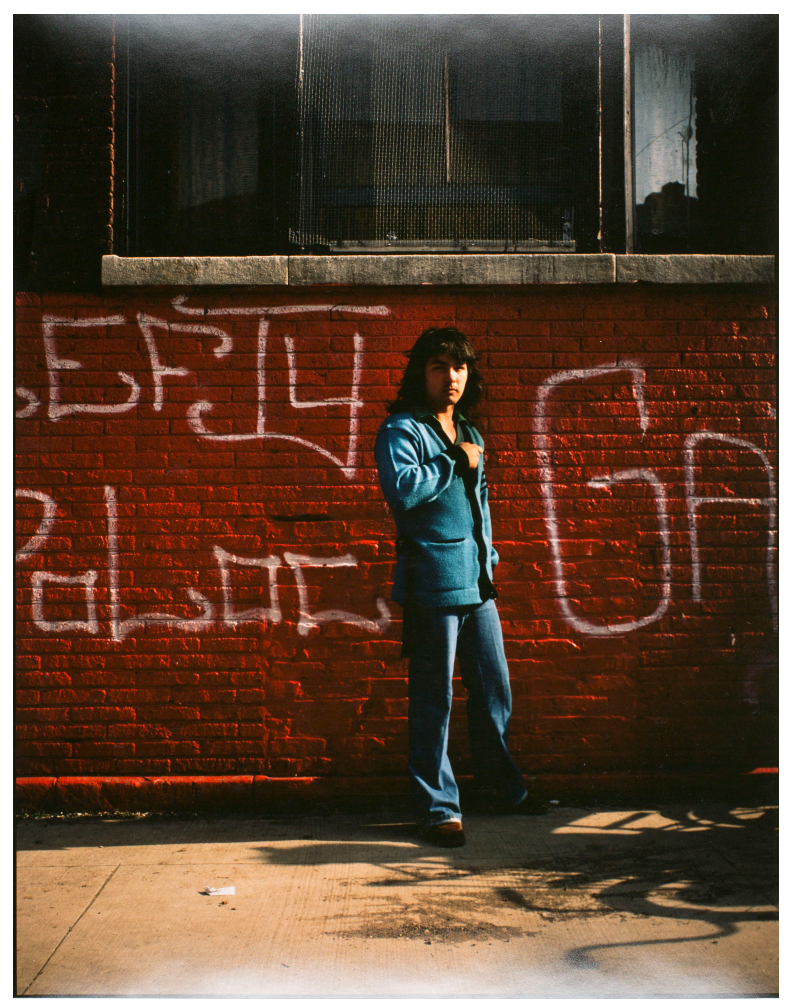

Plate 12: Luis Medina, [untitled, Gang Series], Silver dyebleach print, no date. Courtesy of the Art Institute of Chicago.

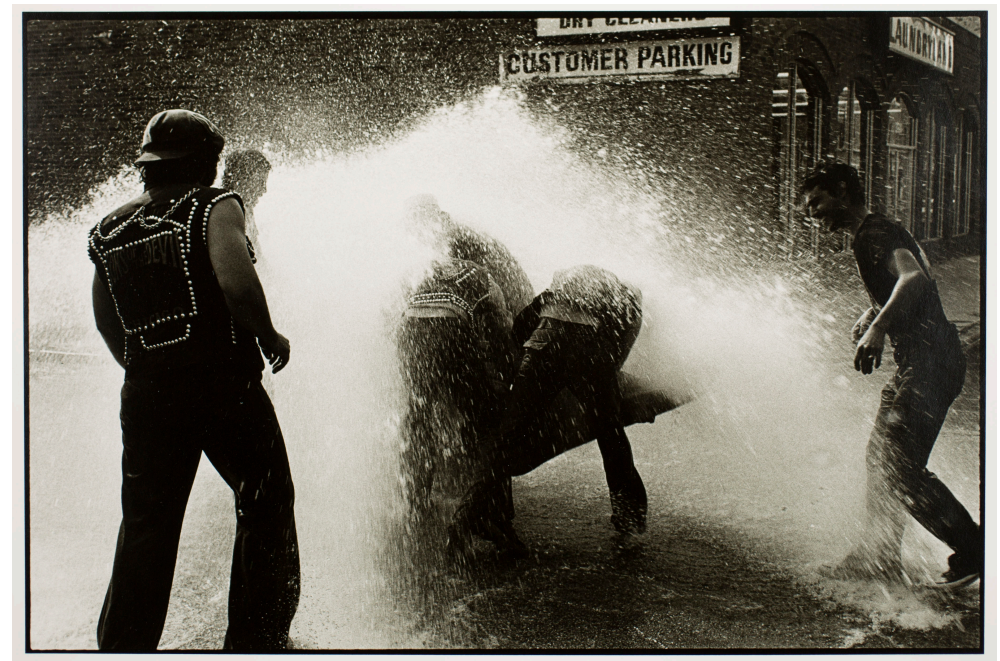

Plate 13: Luis Medina, [untitled, Sons of the Devil Series II], Gelatin silver print, 1980. Courtesy of the Art Institute of Chicago. 


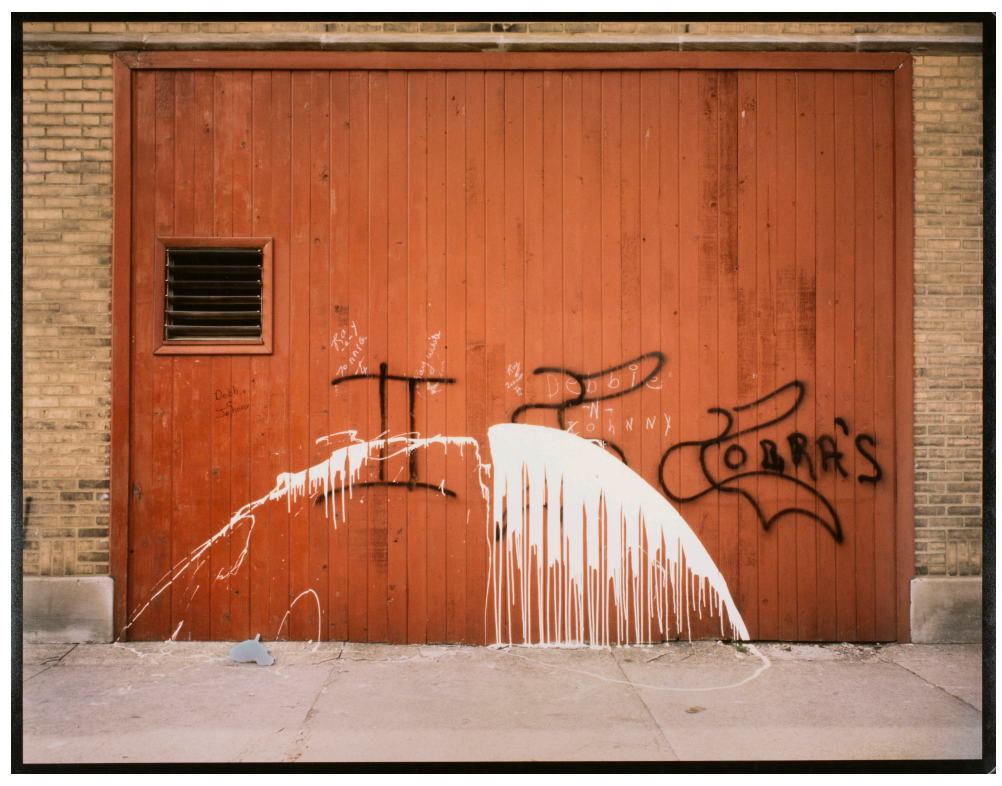

Plate 14: Luis Medina, [untitled, Graffiti Series], Silver dye-bleach print, 1979. Courtesy of the Art Institute of Chicago.

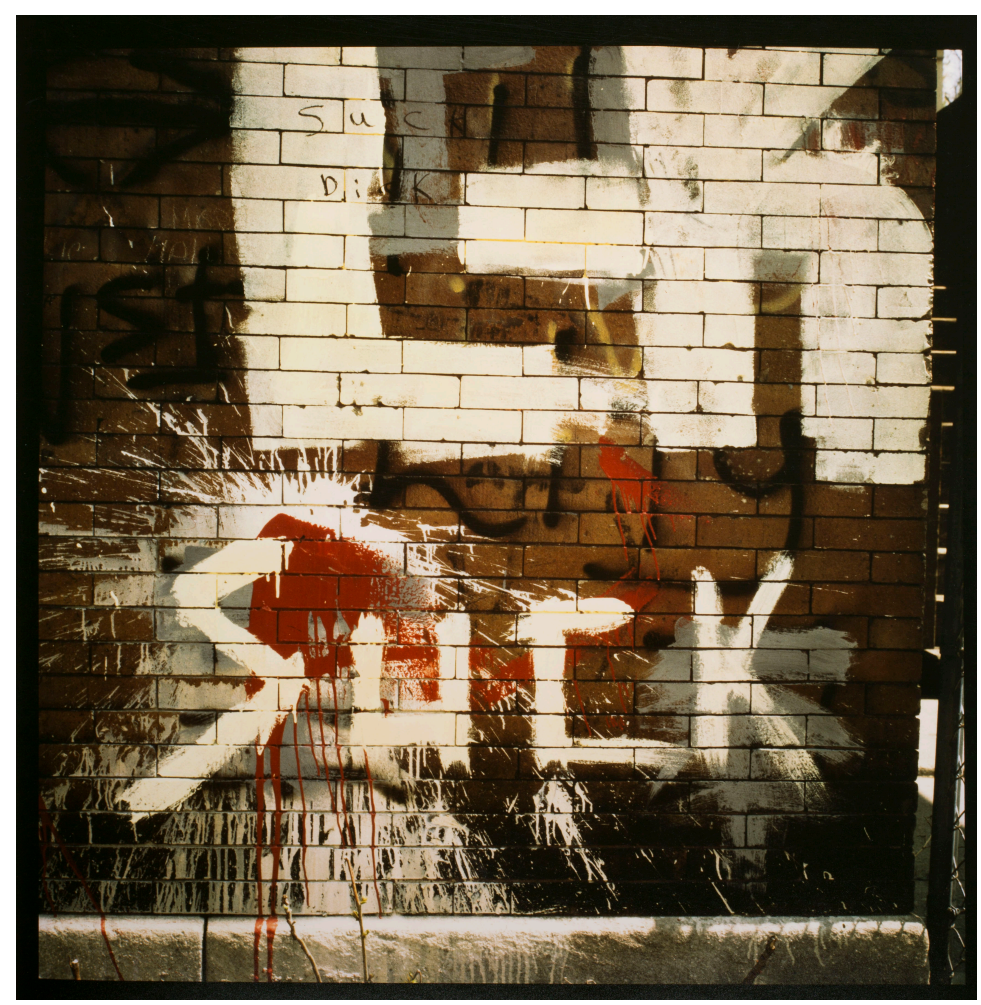

Plate 15: Luis Medina, Graffiti, Silver dye-bleach print, 1979. Courtesy of the Art Institute of Chicago. 


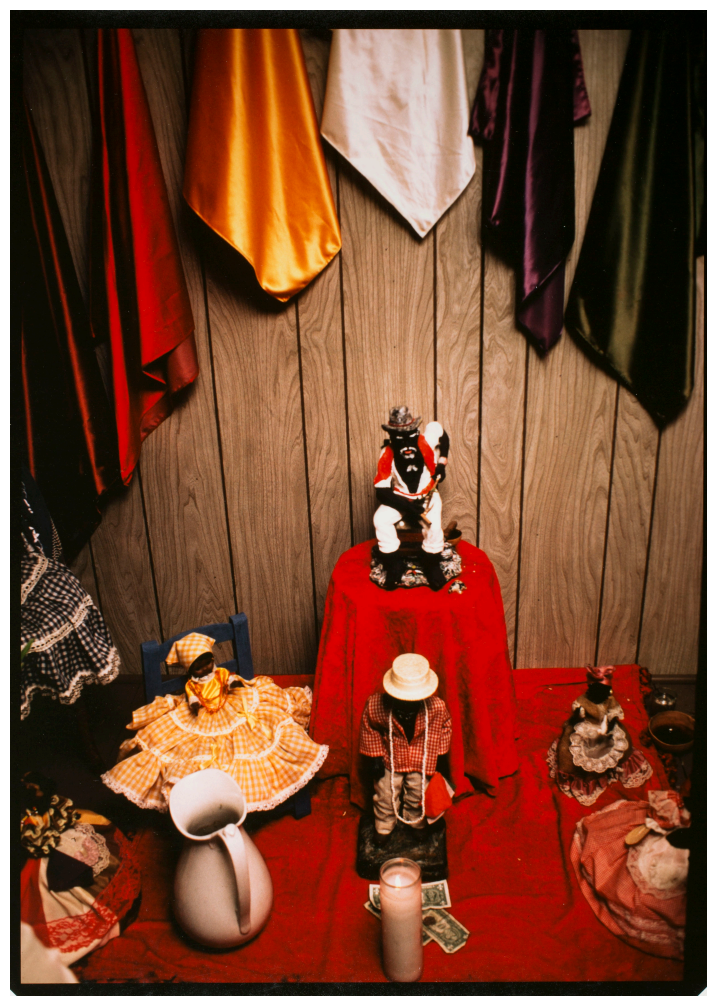

Plate 16: Luis Medina, [untitled, Santería

Worshipping], Silver dye-bleach print, 1981. Courtesy of the Art Institute of Chicago.

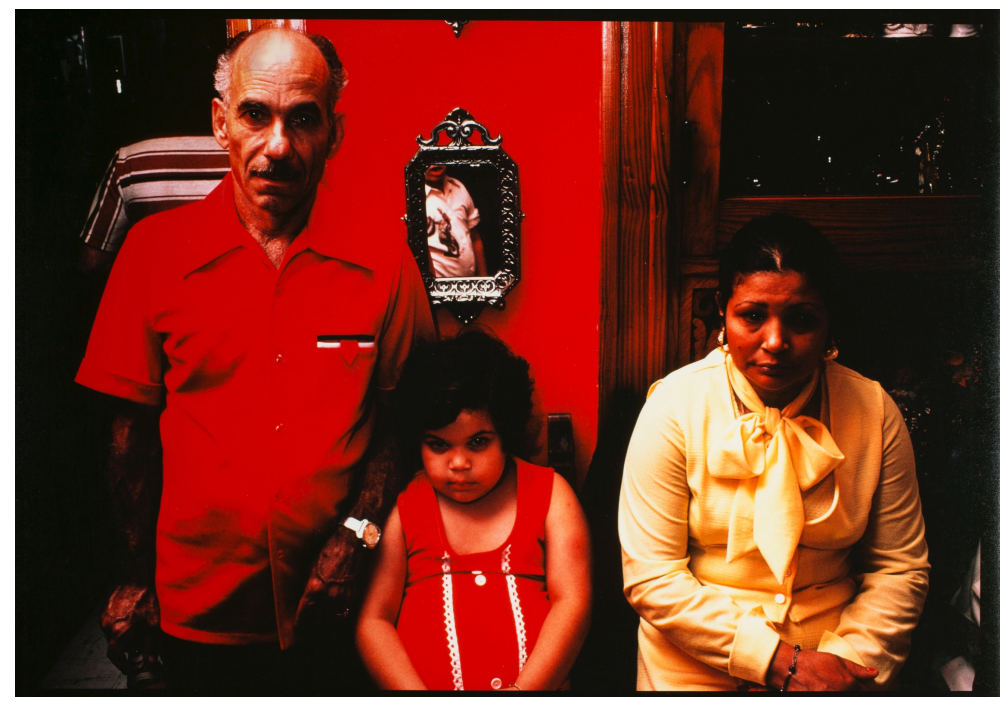

Plate 17: Luis Medina, Saints Feast (Santería Worshipping), Chicago, Silver dye-bleach print, 1980. Courtesy of the Art Institute of Chicago. 
- Upon a review of the slides that were organized with dates and subjects, I advised that a selection should not be made and removed from the archive. The Department of Photography has a policy of not collecting negatives, and as these slides represent Medina's working negatives, they violate this policy. Furthermore, separating them from the archive may negatively impact their research potential since they would lose a lot of the context of their creation and use by Medina.

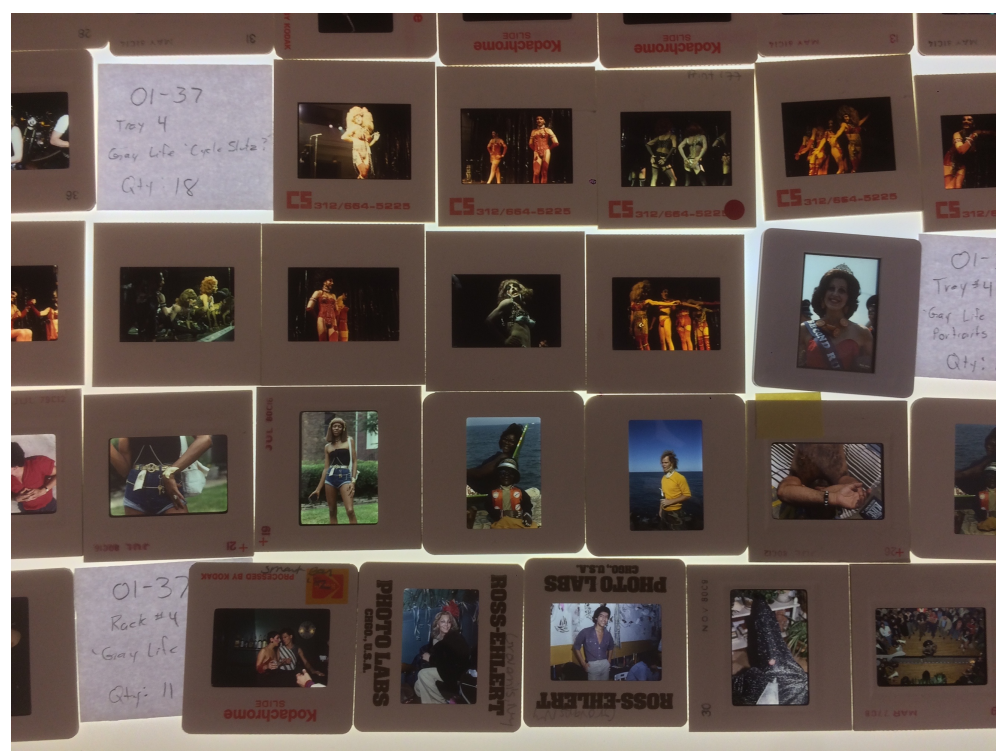

Plate 18: Detail of Medina slides on lightbox, 2017. Courtesy of the author.

- There are also several prints by a selection of other photographers that were in Medina's archive that should be considered for addition to the collection of the AIC. One example is the image Harold Allen made to assist López and Medina in 1969, to which they in turn applied media to illustrate their vision for a project they were developing (see Plate 3).

- Lastly, all ephemera related to the archive should remain within the AIC and be added to the archival collection held in the Ryerson and Burnham Library. These materials, including 
notebooks, correspondences and other related items, are an important source of information that relate directly to the prints held in the permanent collection. As such, making them available to researchers serves an important function, and provides a lot of material to form an improved understanding of the works and the life of Medina.

Upon the completion of my term at the AIC, it was still to be determined what other institutions may be able to give a proper home to the remainder of the collection. The goal is to locate an institution to which the collection can be donated in its entirety; however, the possibility remains of the need to divide it into smaller pieces and donate them to multiple institutions.

With so many images and slides of the Chicago area between 1969 and 1984 it is easy to imagine that institutions whose mandate supports collecting materials relevant to the history of Chicago would benefit greatly from these materials. It would also make future research needs more manageable since all components would be held in a single institution. 


\section{Conclusion}

The goal of this applied project has been to make this collection of materials visible and accessible, both within the AIC and to others who may be interested in exploring them further. Because of my efforts, a new selection of 101 prints are under consideration for accession into the permanent collection. This would increase the total works by Medina at the AIC to 204, an increase of almost 100\%. But more importantly, they include a selection of prints from Medina's "Gay Scene" collection that have never been published or exhibited. This important aspect of his work would finally be represented in the collection of the institution that holds the majority of his works; such an acquisition would add another dimension to his artistic practice, one that has largely remained unknown until now.

In addition, from a practical vantage point, I have left the Department of Photography with a database that provides a full inventory of the holdings of the archive. This makes these materials more accessible than they have ever been and will enable the department to accurately depict the contents of the collection as they determine where they will finally reside. This will prove especially useful in the event the collection is divided and donated to multiple institutions because it will allow them to pull items from their current locations quickly and accurately.

This project has only scraped the surface of the Luis Medina Archive, but it has provided the infrastructure to ensure that these materials will be available for future use. It is hoped that other researchers or archivists will now be able to access the materials, and begin diving deeper into the materials to see what subjects they broach, and what questions they address, both from the perspective of Luis Medina's career. Throughout this project it was obvious to me that the various intersections represented in Medina's career by his archive would provide ample resource 
for sustained research projects. His work provides a unique perspective on several groups largely marginalized, or considered 'outside' mainstream society in 1970/80s America. His work portraying urban gangs, Latin-American culture, LGBTQ culture, and others are fascinating not just as documents of those marginalized groups, but also because of his uniquely expressive style. A melancholic sympathy exists in much of Medina's work, likely because so much of it captures life on the margins of one of America's great cities. In a city that still deals with the problems associated with gang violence, and where a substantial Latin-American culture continues to thrive, it is hard to imagine that Medina's work would not find a welcoming audience, or researchers eager to capitalize on the documents he has left behind.

One of the hallmarks of the Department of Photography at the Art Institute of Chicago, and indeed one of its most inspiring features, is the accessibility to the collection that the institution provides to researchers and the public. It is this spirit of accessibility which must now resolve to settle the question of how to properly handle the contents of the Luis Medina Archive. Doing so will honour this legacy, and provide the opportunity to make this resource available for future research. Though the permanent collection includes many excellent photos by Medina, they do not tell the full story of his career, so the importance of these archival materials cannot be understated. Perhaps, this project has altered the circumstances of the Luis Medina Archive enough to continue the work needed to bring order and accessibility to this body of work. Doing so will add a new resource that can contribute to the bodies of knowledge whose interests intersect with the works in this archive.

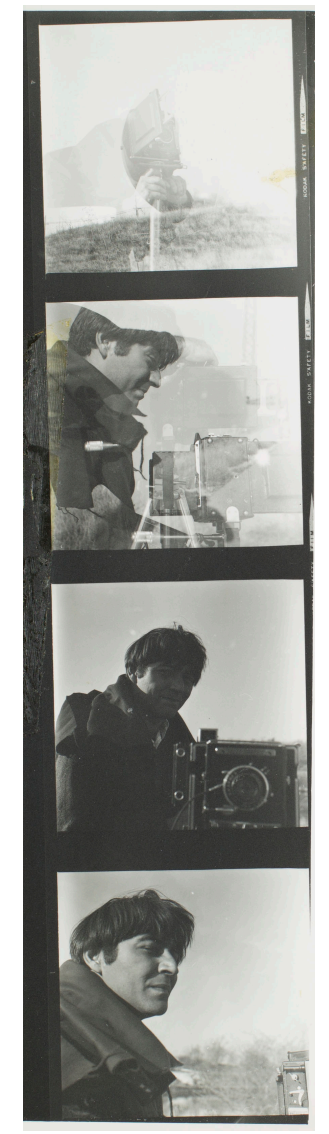

Plate 19: unknown, Luis Medina, no date. Courtesy of the Art Institute of Chicago. 


\section{Bibliography}

Allen, Harold. Harold Allen, Photographer and Teacher. Chicago: Art Institute of Chicago, 1984.

Brown, Elspeth H., and Thy Phu eds. Feeling Photography. Durham: Duke University Press, 2014.

Buck, Rebecca A., and Jean Allman Gilmore. MRM5: Museum Registration Methods. 5th ed. Washington, DC: AAM Press, 2010.

Campany, David. Art and Photography. London: Phaidon Press Limited, 2003.

Cvetkovich, A., V. Davis, J. Doyle, J. Halberstam, D. Frantz, and M. Locks. Cruising the Archive: Queer Art and Culture in Los Angeles, 1945-1980. Los Angeles, CA: One National Gay $\mathcal{E}$ Lesbian Archives, 2011.

Eskildsen, Ute, Florian Ebner, and Bettina Kaufmann. Street E Studio: An Urban History of Photography. London: Tate Pub., 2008.

Frizot, Michel, ed. A New History of Photography. Köln: Könemann, 1998.

Gervais, Thierry ed. The Public Life of Photos. Toronto: RIC Books, 2016.

Grimbert, Patrice, José López, and Luis Medina. Dreams in Stone: University of Chicago. Chicago: University of Chicago, 1976.

Hackett, Sophie, and Jim Shedden. Outsiders: American Photography and Film 1950s-1980s. New York: Skira Rizzoli Publications, Inc., 2016.

Hanly, Elizabeth. "Santería: An Alternative Pulse." Aperture no. 141 (Fall 1995): 30-37.

Kozloff, Max. Photography E Fascination. New Hampshire: Addison House, 1979.

Lavedrine, Bertrand. A Guide to the Preventive Conservation of Photograph Collections. Los Angeles, CA: Getty Conservation Institute, 2003.

Lyon, Danny. The Bikeriders. New York, NY: The MacMillan Company, 1968. 
—. "Urban Combat." Aperture no. 96 (Fall 1984): 30-33.

Marien, Mary Warner. Photography: A Cultural History. Upper River Saddle, NJ: Prentice Hall, 2002.

Pénichon, Sylvie. Twentieth-Century Color Photographs: Identification and Care. Los Angeles, CA: The Getty Conservation Institute, 2013.

“Gallery: Four Eyes - One Vision,” Nuestro Magazine, April 1977.

Squiers, Carol. Over Exposed: Essays on Contemporary Photography. New York, NY: New Press, 2000.

Terpak, Frances, Michelle Brunnick. Robert Mapplethorpe: The Archive. Los Angeles: Getty Research Institute, 2016.

Travis, David. Facts and Fables by Luis Medina. Chicago, IL: Art Institute of Chicago, 1993.

- Photography in Chicago Collections: Selected to Mlustrate the History of the Art of Photography and to Inaugurate the New Galleries and Facilities of the Department of Photography. Chicago: The Art Institute of Chicago, 1982.

- At the Edge of the Light: Thoughts on Photography 6 Photographers, Talent $\mathcal{E}$ Genius. Boston: David R. Godine, 2003.

Travis, David, and Elizabeth Siegel. Taken by Design: Photographs from the Institute of Design, 1937-1971. Chicago: Art Institute of Chicago in Association with the University of Chicago Press, 2002.

Tschan, Reto. "A Comparison of Jenkinson and Schellenberg on Appraisal." Accessed April 26, 2017. americanarchivist.org/doi/pdf/10.17723/aarc.65.2.920w65g321770611.

Warren, Lynne, and Jeff Abell. Art in Chicago 1945-1995. New York: Thames and Hudson, 1996.

Wise, Kelly, and Max Kozloff. The Photographers' Choice A Book of Portfolios and Critical Opinion. Danbury, NH: Addison House, 1975. 